\title{
Do Board Expertise and Networked Boards Affect Environmental Performance?
}

\author{
Swarnodeep Homroy ${ }^{1}\left[\right.$. Aurelie Slechten ${ }^{2}$
}

Received: 28 April 2017 / Accepted: 10 December 2017 / Published online: 21 December 2017

(c) The Author(s) 2017. This article is an open access publication

\begin{abstract}
We examine the resource provision role of the board of directors in ensuring substantive corporate sustainability practices. Specifically, we examine two channels of resource provision (i.e., the presence of non-executive directors with previous experience in environmental issues-EEDs-and network connections of EEDs) that can affect a firm's ethical and environmental behavior. Using greenhouse gas (GHG) emissions data from FTSE 350 firms, as a measure of environmental performance, we show that the presence of EEDs on the board is associated with lower GHG emissions. Further, firms with better-networked EEDs have better environmental performance. A possible mechanism is that firms with EEDs invest more in environmental technology. These results suggest that, in addition to the traditional role of shareholder value maximization, the board of directors also caters to the interests of wider stakeholders of the firm by facilitating substantive ethical practices.
\end{abstract}

Keywords Director expertise $\cdot$ Director networks $\cdot$ Emissions $\cdot$ Environmental performance

JEL Classification G34 $\cdot \mathrm{G} 39 \cdot \mathrm{L} 14 \cdot \mathrm{L} 25 \cdot \mathrm{Q} 50$

\section{Introduction}

Environmental impact of production and business activities is one of the most pressing questions of our times. Firms are under increasing institutional pressure to be environmentally responsible, and this pressure manifests in different ways. Most countries have now issued codes of ethical practices on environmental sustainability (e.g., in the USA, the Ceres Principles are a ten-point code of corporate environmental conduct, publicly and voluntarily endorsed by companies). At a more global level, international certification standards for environmental management have been developed: the ISO 14001 introduced in 1996 by the International Organization for Standardization or the Eco-Management and Audit Scheme (EMAS) launched by the European Commission in 1993. Corporate environmental disclosures are also

Swarnodeep Homroy

s.homroy@rug.nl

1 Faculty of Economics and Business, Department of Economics, Econometrics and Finance, University of Groningen, Groningen, Netherlands

2 Department of Economics, Lancaster University, Lancaster, UK receiving increased scrutiny by national authorities. ${ }^{1}$ For example, in the UK, under the Companies Act 2006, listed companies are required to report greenhouse gas (GHG) emissions since October 2013. All these initiatives aim at improving firms' ethical behavior in terms of environmental sustainability and their success is likely to depend on how the corporate sector responds to them. Yet, there is little evidence on how firms internalize these institutional pressures or how corporate governance impacts upon the environmental performance of firms.

In this paper, we focus on some factors that may help firms adopt substantive actions toward environmental sustainability. In particular, we examine the role of specific skills and networks of directors in shaping the environmental performance of firms through information agglomeration. Because of the increasing importance and the strategic nature of environmental issues, the board of directors is likely to influence a firm's environmental policy. Moreover, due to the long-term and complex nature of environmental problems, the resource provision role of the directors will be

\footnotetext{
${ }^{1}$ For further evidence on the impact of institutional framework on corporate social and environmental disclosures, see Khlif et al. (2015).
} 
crucial. We focus on two channels through which directors can agglomerate information and provide relevant advice to the management to improve a firm's environmental performance. First, a director with specific environmental experience (henceforth EED) can narrow the information gap between the board and the management (Pfeffer and Salancik 1978). Second, well-connected EEDs can facilitate the exchange of information on environmental strategies across the boundaries of the firm.

These are important questions in the business ethics and corporate finance literature for two reasons. First, they shed light on how governance practices can affect environmental performance and corporate ethical behaviour more broadly. Second, they provide evidence on how director expertise matters in sustainable strategic decision making. More specifically, our results highlight the board characteristics policymakers and shareholders have to target to enhance firms' environmental performance. For example, regulations such as the Companies Act 2006 in the UK make the directors responsible for the environmental impact of the firm. Such individual accountability must be in sync with the influence directors have on environmental performance.

To this end, we use GHG emission data from the European Pollutant Release and Transfer Register (E-PRTR), as a measure of a firm's environmental performance, and information on the board composition and director networks of FTSE 350 firms from BoardEx. Our sample comprises an unbalanced panel of 274 firms for the period 2006-2014. We measure environmental expertise with the presence of at least one EED and board-level committees on sustainable issues. To address the second question, we focus on the EEDs network formed by shared directorships: two directors are connected if they sit on the same board in a given year. We evaluate how well-networked an individual EED is (and so the ease of accessing information across the boundaries of the firm), by computing four measures of connectedness. These measures capture different aspects of the quality of an EED's connections that are relevant for the transmission of information within the EED network.

In estimating the effect on the environmental performance of board expertise and director networks, it is important to control for potential bias introduced by endogenous appointment of EEDs or better-networked directors in certain firms. In addition to adjusting for firm and year fixed effects to mitigate time-invariant omitted variable bias, we control for a range of firm and industry characteristics. When investigating whether the presence of EEDs and board-level committees on sustainable issues affect environmental performance, we also use two-stage least square estimations to control for bias induced by time-varying unobservables. In particular, we focus on the potential bias introduced by assortative sorting between EEDs and firms. This sorting can be either positive if EEDs only accept jobs in firms with low GHG emissions (for reputation issues for example) or negative if the demand for EEDs is higher in firms with high GHG emissions. We instrument the appointment of EEDs with a measure of the supply of potential directors with environmental expertise. A higher supply of directors with environmental expertise is likely to lower the cost of appointing such directors on boards, but should not directly influence an individual firm's environmental performance. We find an economically meaningful effect of having EEDs on the board, particularly if these directors are members of board-level committees focused on environmental issues. These results are robust to different classifications of EEDs and board committees for environmental issues.

Regarding our second question, we find that better-networked EEDs are associated with lower GHG emissions. However, it is possible that this result is driven by the endogenous selection of more skilled directors (who tend to have larger networks) to firms with better environmental performance. Masulis and Mobbs (2011) show that endogenous matching on director skills can drive the results of board connections and financial performance of firms. We perform an array of tests to examine possible endogeneity in board composition and director networks. The results of these tests also support the view that the negative association of board networks and GHG emissions are driven by better access to information.

Finally, when investigating the impact of EEDs on other corporate outcomes, we find higher levels of capital expenditures, and research and development expenses in firms with EEDs and better-networked EEDs compared to firms without. This suggests that a possible mechanism through which EEDs can affect GHG emissions is through investments in green technologies.

Our findings add to several strands of business ethics, and corporate finance literature. First, we contribute to the literature in business ethics analyzing how governance structure can effectively influence corporate ethical and environmental behavior. The fundamental questions in the business ethics literature are why and how do firms ensure environmental sustainability? (Walker and Wan 2012). In answering the 'why' question, the role of the board of directors to protect the interests of the shareholders is much studied (Bebchuk and Weisbach 2010; Cohen et al. 2004). In this paper, we focus on the 'how' question. While exploring how governance mechanisms can affect a firm's environmental sustainability, we also shed light on the debate between green-washing and active corporate environmental management (Laufer 2003; Walker and Wan 2012). It is of interest to understand how firms can set up formal governance mechanisms to ensure ethical behavior, and whether such actions are symbolic or substantive. We examine how firms can internalize pressures to be sustainable and respond to these pressures with substantive ethical practices. Our results suggest that 
proactive environmental management practices include the appointment of directors with relevant skills and network connections and that these practices directly influence firms' ethical behaviour in terms of environmental sustainability.

In that respect, our paper is related to the literature on firms' voluntary measures related to environmental sustainability. The prior literature has examined the motivations of firms to participate in voluntary environmental management and climate change programmes, and the implications for environmental performance (Anton et al. 2004; FisherVanden and Thorburn 2011). These papers have highlighted the impact of firm size, profitability, access to financing, regulatory and stakeholder pressures on the uptake of voluntary environmental practices by firms. Elsayed (2006) also shows that firm size and available resources are significant predictors of corporate environmental performance. A key distinction of our paper is that we focus on specific environmental expertise rather than a more general directorial expertise and on the quality of board connections rather than only the number of these connections.

The existing literature analyzes the impact of various board characteristics on corporate social or environmental performance (Rao and Tilt 2016; Walls et al. 2012). Some studies also investigate the relationship between a measure of environmental performance and the two board characteristics we are focusing on, namely expertise and connections. Ortizde-Mandojana et al. (2012) show that multiple directorships (i.e., the number of boards a director is connected to) have a positive impact on the adoption of proactive environmental strategies by the firm. Two other papers (Kassinis and Vafeas 2002) examine the relationship between board characteristics and the number of violations of environmental legislation. While Kassinis and Vafeas (2002) find weak evidence that prosecuted firms have directors with fewer multiple directorships, McKendall et al. (1999) find that the presence of attorneys on the board is not significantly related to the number of environmental violations. de Villiers et al. (2011) is the paper the most closely related to ours as they also investigate the advisory and monitoring roles of the board of directors in shaping a firm's environmental performance. They show that firms with a larger representation of CEOs from other boards and more legal experts have better environmental performance. They don't find any effect of multiple directorships.

Furthermore, we add to this business ethics literature by using a quantitative and comparable measure of ethical behavior, i.e., the level of greenhouse gas emissions. The majority of studies use an aggregated score-based measure (KLD) as a proxy for environmental performance (Di Giuli and Kostovetsky 2014). While this provides a measure to rank firms, it subsumes the underlying distribution of emissions. Some other studies use negative environmental events like oil spills, government enforcement actions, lawsuits, etc. (Klassens and McLaughlin 1996; Konar and Cohen 2001).
These measures, while useful in studying a particular type of pollution or an event, doesn't provide an objective and comparable measure of firms' environmental performance.

Second, our paper is related to the literature on the advisory role of the board and directors' expertise. While the monitoring role of the board of directors has been extensively researched, recent work highlights the importance of the advisory role, specifically when directors have relevant expertise and when the regulatory environment is complex (Dass et al. 2014; Coles et al. 2008). The financial, legal, industry, and political expertise of directors have been well studied (Güner et al. 2008; Goldman et al. 2009; Dass et al. 2014). These papers provide evidence on the financial benefits to a firm from related expertise of directors. A key distinction of our paper is that we examine the effect of director expertise on environmental strategy, which is likely to involve large capital expenditures with uncertain returns, are institutionally complex, and can have long-term value implications (Konar and Cohen 2001). Moreover, the impact of director expertise on GHG emissions is more than a specific case of the above-mentioned results because environmental and financial performance presents a short-term trade-off to the firm. Director expertise may not affect in similar ways sustainability issues as it does for firm value.

Finally, we contribute to the literature on connected boards. Existing literature studies the effect of director/CEO connections on the financial performance of firms (Hwang and Kim 2009). There is evidence on the impact of the social network of directors on venture capital (Hochberg et al. 2007), managerial compensation (Hwang and Kim 2009), and lending markets (Garmaise and Moskowitz 2003). More closely aligned to this paper is the burgeoning literature on innovation economics and corporate governance that looks at how firm investment into innovation is affected by CEO types or characteristics (e.g., Gomes-Casseres et al. 2006; Acemoglu et al. 2014). For example, Gomes-Casseres et al. (2006) show that innovations and patent filings are associated with board network connections. Our paper adds to this literature by examining how knowledge-flow through director networks affects GHG emissions.

\section{Theory and Hypotheses}

\section{Resource Dependence Perspective to Substantive Ethical Practices}

Environmental sustainability has become a salient business issue in the recent times. Faced with pressures to engage in sustainable practices, firms either react symbolically (Westphal and Zajac 1998) or take substantive actions to reduce their environmental impact (Fisher-Vanden and Thorburn 2011). Either way, the aim is to communicate to the 
stakeholders about the ethical stance and gain legitimacy on ethical practices. Obtaining such legitimacy is useful to firms as they benefit from better access to resources, and better performance (Klassens and McLaughlin 1996; Konar and Cohen 2001). Rationally, we can expect firms to reduce the cost of compliance and engage in symbolic ethical practices. However, Walker and Wan (2012) argue that symbolic environmental practices negatively affect firms, and financial benefits can only be derived from substantive ethical practices.

Given the link between environmental and financial performance, it is important to understand how firms can ensure substantive ethical practices. While previous studies have focused on firms' communication about green technology, we focus on more costly and hence arguably more impactful and substantive actions (Stevens et al. 2005). With increasing importance of environmental sustainability, these issues should fall under the purview of the board of directors, which forms the "apex" of decision making and corporate control, primarily tasked with monitoring and advising senior management (Fama and Jensen 1983; Adams et al. 2010). While the monitoring role of the board of directors has been extensively researched, this study investigates the advisory role of the board. This role is based on the resource dependence theory, which suggests that directors facilitate access to resources and narrow the information gap between the board and the management (Pfeffer and Salancik 1978). Resource and information provision is particularly important in this context as environmental issues may involve large capital expenditures with uncertain and long-term returns and are institutionally complex. Firms will seek advice from the board of directors to form their environmental strategy and can benefit from access to relevant information about environmental impacts, good environmental practices, new environmentally efficient technologies (and their implementation costs), etc.

In their seminal work, Pfeffer and Salancik (1978) identify the possible channels through which directors can enhance the access of firms to resources. These include providing counsel, opening up access to information beyond the boundaries of the firm, and ensuring a better connectedness to the broad information network. We use this framework to identify two possible channels through which boards can agglomerate useful information and advise the management. First, the quality of counsel will depend on the expertise of their own directors in environmental matters. Therefore, we identify director expertise in environmental sustainability as a potential channel of resource provision. Second, directors can serve as conduits of information agglomeration across different firms. In that sense, the connectivity of the directors, specifically the directors with environmental expertise, is likely to be another channel to provide resources relevant to the firm's environmental strategy.

\section{Environmental Expert Directors (EEDs) and GHG Emissions}

Recent works on the functions on corporate boards highlight the importance of the advisory role, specifically when directors have relevant expertise and when the regulatory environment is complex (Dass et al. 2014; Coles et al. 2008). These papers provide evidence on the importance of legal, political, and industry experience of non-executive directors. For example, Dass et al. (2014) show that firms benefit from appointing directors with specific experience of working in related industries. Another area where firms can benefit from the specific expertise of the directors is environmental sustainability. This is due to various aspects of environmental issues: the complexity and the number of environmental regulations, the extent of capital expenditures that implementing environmental practices may involve, their longterm impacts, etc.

Firms engaging in substantive ethical practices may seek to appoint a director with environmental resources (i.e., EED). EEDs with specific human capital are in a better position to offer counsel on environmental issues and provide better resource access to firms. They are more likely to bring to light the elements of environmental management that are the most critical and the most suitable for the firm than a director without this expertise. However, firms may incur search cost to appoint EEDs, and appointing EEDs may keep out directors with other specific skills which are valuable to the firm. This is why we expect the presence of an EED to be indicative of substantive ethical practices and to be positively associated with environmental performance.

H1 Director expertise in environmental sustainability is associated with lower GHG emissions.

We also explore a possible channel through which EEDs can impact upon GHG emissions. Recent results show that boards are increasingly functioning through committees (Adams 2003; Billmoria and Piderit 1994; Laux and Laux 2009). These committees are focused on specific tasks like audits of financial accounts, the nomination of new directors, managing environmental risks, etc. They are shown to be effective governance mechanisms (Guo and Masulis 2015). If the allocation of resources in the board is optimal, we will expect EEDs to sit at board-level committees focused on environmental risks and performance. However, matching of director expertise to committee roles is a recent phenomenon. For example, till 2012 JPMorgan Chase had no directors with risk expertise on the risk committee. We hypothesize that firms, where EEDs are assigned to environmental committees, are likely to benefit in terms of environmental performance, compared to firms where EEDs are not assigned to environmental committees. Together with 
Hypothesis 1, we explore how specific expertise of directors in environmental sustainability affects GHG emissions, through environmental board committees.

H2 The assignment of directors with environmental expertise to board committees focused on environmental issues is associated with further reductions in GHG emissions.

\section{EED Networks and GHG Emissions}

The second way through which EEDs can ease the access to resources and information is by leveraging their social capital across organizational boundaries. Firms differ in the use of environmental technologies; hence, better-networked EEDs (i.e., EEDs with a better connectedness with other EEDs) are likely to have better access to resources and information regarding good environmental practices used in other companies. By sharing directorship in different companies, EEDs are exposed to various environmental strategies or investment opportunities and can exchange information related to environmental issues. They may, therefore, have a comparative advantage in their advisory role (Larcker et al. 2013). In a similar context, Kassinis and Vafeas (2002) show that directors accumulate human capital from their multiple board affiliations and can lead to fewer environmental litigations.

At the same time, it is possible for value-destroying practices to be propagated through director networks: EEDs sitting on the boards of many different firms spend less time to advise an individual firm or engage in collusive practices on environmental sustainability issues (Fich and Shivdasani 2006). These practices may negatively impact upon environmental performance. If the first effect dominates (i.e., better access to information), then the expertise and network channels will reinforce each other and the benefits accrue to firms, which appoint better-connected EEDs. On the other hand, if the collusive practices dominate, we expect the network effect to offset partially the expertise effect. The resource dependence argument is that the net effect of director connectedness on the firm should be positive, notwithstanding the possibility of reduced monitoring (de Villiers et al. 2011). Based on that, we test the hypothesis that information spillovers through EED networks positively influence environmental performance.

H3 EED networks facilitate their resource provision role and are associated with lower GHG emissions.

\section{Data and Variables}

In this section, we discuss the data sources, variables construction and sample selection for our empirical tests.

\section{Sample Selection}

Our sample is taken from listed UK firms featured in the FTSE 350 index over the period 2006-2014. From Datastream, we collect information on performance, size, risk in the operating environment and industry classifications. We augment this with information on individual directors, board composition and board networks of these firms using BoardEx. Finally, firm-level environmental emissions data are obtained from the European Pollutant Release and Transfer Register (E-PRTR).

To be included in our sample, firms have to feature in the FTSE 350 for at least two consecutive years, have the full set of board characteristics, and have relevant financial data available. With these constraints, we have an unbalanced panel of 375 firms. Once included, we continue to follow a firm unless it is acquired or taken private.

From this sample, we drop firms for which no director has any network connections. We augment the FTSE 350 sample with network centrality measures (defined below) of individual EEDs using information available from BoardEx. To calculate the network centrality measures, we use shared directorships from all quoted boards in Europe. As an additional sample selection criterion, we require that firms have pollution data (from E-PRTR) for all years. This restricts our sample to an unbalanced panel with 4143 firm-year and 18,098 director-year observations.

Finally, not all industries pollute through GHG emissions. We restrict our sample to firms from GHG emitting industries only and exclude firms in Financial and IT industries. Our final sample consists of an unbalanced panel with 3244 firm-year and 16,212 director-year observations. Table 1 and "Appendix 1" summarize the key variables of the sample.

\section{Measuring Environmental Performance}

As a measure of firms' environmental performance, we use firms' GHG emission data from the E-PRTR. The E-PRTR provides annual pollution data from more than 30,000 facilities in Europe over the period 2007-2014 across several industrial sectors. It provides data on releases of pollutants to air, water and land as well as off-site transfers of waste and of pollutants in wastewater from 93 key pollutants, including heavy metals, pesticide, greenhouse gases and dioxins. The main advantage of the register is that data are comparable across countries and pollutants because data collection and reporting are standardized overall pollutants in all countries (see “Appendix 2" for details).

Pollution data in the E-PRTR is at the facility-levelwhere a facility is an operation unit of a firm focused on a narrowly defined process like packaging, bottling, etc. To arrive at the firm-level emission data, we aggregate GHG emissions for all European facilities of an FTSE 350 firm. 
Table 1 Descriptive statistics of key variables

\begin{tabular}{|c|c|c|c|c|}
\hline & $\mathrm{N}$ & Mean & Median & SD \\
\hline GHG emissions (normalized) & 3244 & 12.085 & 6.762 & 26.110 \\
\hline EED dummy & 3244 & 0.094 & 0.000 & 0.144 \\
\hline Number of EEDs & 3244 & 1.470 & 1.089 & 1.986 \\
\hline Environmental Committee & 3244 & 0.47 & 0.40 & 0.084 \\
\hline Degree & 3244 & 4.107 & 3.085 & 2.239 \\
\hline Closeness & 3244 & 0.294 & 0.217 & 0.016 \\
\hline Betweenness & 3244 & 0.020 & 0.035 & 0.018 \\
\hline Eigen vector & 3244 & 0.054 & 0.073 & 0.040 \\
\hline ROA & 3244 & 7.802 & 6.126 & 6.546 \\
\hline MTBV & 3244 & 1.501 & 0.334 & 2.620 \\
\hline Ln sales & 3244 & 17.422 & 11.215 & 6.874 \\
\hline Leverage & 3244 & 0.556 & 0.511 & 0.0282 \\
\hline Volatility & 3244 & 0.039 & 0.044 & 0.021 \\
\hline Slack & 3244 & 0.225 & 0.137 & 0.259 \\
\hline Firm Age & 3244 & 3.012 & 2.828 & 1.605 \\
\hline $\mathrm{R} \& \mathrm{D}$ & 3244 & 0.049 & 0.003 & 0.033 \\
\hline Capital expenditure & 3244 & 0.594 & 0.022 & 0.584 \\
\hline CEO pay ('00,000 US\$) & 3244 & 13.282 & 8.705 & 5.357 \\
\hline CEO turnover & 3244 & 0.194 & 0.122 & 0.067 \\
\hline HHI & 3244 & 0.211 & 0.203 & 0.194 \\
\hline CEO duality & 3244 & 0.230 & 0.000 & 0.301 \\
\hline$\%$ Shareholding-Institutions & 3244 & 28.242 & 22.108 & 20.491 \\
\hline Board Size & 3244 & 8.143 & 7.988 & 2.660 \\
\hline$\%$ Non-executive directors & 3244 & 55.309 & 51.342 & 24.143 \\
\hline Average board tenure & 3244 & 6.273 & 4.114 & 2.527 \\
\hline No. of law expert & 3244 & 1.185 & 1.000 & 0.876 \\
\hline
\end{tabular}

All monetary values are expressed in constant 2010 US\$

This aggregation process requires multilevel matching. E-PRTR reports the parent firm of each facility. We first aggregate the information of all facilities that have the same parent firm. 281 of these parent companies reported by the E-PRTR are not publicly listed firms themselves, but are wholly owned subsidiaries of listed firms. We map these subsidiaries to the listed firms by using information available from Osiris. This matching exercise yields 89 unmatched firms. We manually supplement the missing information on parent firms from the publicly available news and drop from the sample firms where no information is available. This leads to omission of 40 firms. Our measure of GHG emissions is standardized by the threshold level of pollutant. The reporting thresholds are set up by the European Commission based on their impact on human health and on the environment. For example, the reporting threshold for $\mathrm{CO}_{2}$ is 100 million $\mathrm{kgs} /$ year.

We validate our matching algorithm by comparing our agglomerated GHG emission data with the GHG emission data available from Datastream. We use the ENERDP123 field in Datastream that reports the annual total GHG emissions as $\mathrm{CO}_{2}$ equivalents. By using our agglomeration algorithm, we have improved upon the coverage of Datastream by $32.37 \%$ : on average Datastream reports GHG emissions for 207 firms across the sample period whereas we could calculate GHG emissions of 274 firms. The correlation of the GHG measure reported by Datastream and our measure is 0.809 . Given the wider coverage of our measure, we use our GHG emission data in the baseline regressions and test for the robustness of our results using the subsample of firms with GHG emission data from Datastream.

We also check for the robustness of our results using two other measures of environmental pollution (aggregated at the firm level using the same type of algorithm): emissions of other gases like sulfur and nitrogen oxides, ammonia, chlorofluorocarbons, etc., and release of hazardous and nonhazardous waste.

\section{EED Skills and Networks}

\section{Environmental Expertise}

We identify three different sources of director expertise in environmental issues. First, we use information provided by BoardEx on individual directors' background to control for specific experience in environmental sustainability. Following the sample selection protocol used by Berrone and Gomez-Mejia (2009), we classify a director as EED if the job description of a previous role contains keywords like "environment", "ecology", "pollution", "sustainable", etc. ${ }^{2}$ Information on committee formations allows us to identify directors with experience on board sub-committees that have an environment/pollution control focus. Finally, we use information on awards for and recognition of individual directors on environmental issues. ${ }^{3}$ It is important to note that we only take into account previous experience in environmental roles to classify EEDs. For example, if a director is appointed on an environmental committee in firm $F_{1}$ in period $t$, we do not classify her as an EED in firm $F_{1}$ in subsequent time periods $t+1, t+2, \ldots$ However, we will classify her as an EED in another firm $F_{2}$ if she is appointed in this firm $F_{2}$ in the periods $t+1, t+2, \ldots$

It is possible that we do not have complete information on environmental sustainability-related roles, and environment-related awards of directors, and this can be a likely source of attenuation bias. In that regard, our results will

\footnotetext{
2 All variants of these words are used to encode environmental experience. A complete list of these keywords is presented in "Appendix 3".

${ }^{3}$ Such awards include environmental leadership awards, global cross millennium awards for corporate environmental leadership, etc.
} 
Table 2 Industry composition of the sample

\begin{tabular}{llrrllll}
\hline Industry & No. of firms & EED (No.) & GHG & Degree & Closeness & Betweenness & Eigenvector \\
\hline Energy & 23 & 131 & 16.230 & 5.012 & 0.338 & 0.025 & 0.057 \\
Industrial & 82 & 78 & 15.429 & 4.878 & 0.267 & 0.024 & 0.052 \\
FMCG $^{\text {a }}$ & 77 & 82 & 10.188 & 3.603 & 0.256 & 0.018 & 0.046 \\
Pharmaceuticals & 31 & 110 & 11.536 & 5.212 & 0.314 & 0.027 & 0.057 \\
Healthcare & 38 & 72 & 9.006 & 3.395 & 0.270 & 0.020 & 0.049 \\
Utilities & 23 & 88 & 13.319 & 3.404 & 0.281 & 0.019 & 0.047 \\
\hline
\end{tabular}

${ }^{\mathrm{a} F a s t-m o v i n g ~ c o n s u m e r ~ g o o d s ~}$ be conservative estimates of the impact of these variables on environmental performance.

For encoding the environmental experience of directors, we use the subsample of non-executive independent directors: individuals who are less aligned with management have a lower incentive to maximize short-term profits and are more likely to influence the environmental performance (Byrd and Hickman 1992; Johnson and Greening 1999). Our measure of director expertise is a binary indicator of environmental expertise, which is equal to one if any of the three measures discussed above are relevant to that director in a given year. To give an example, independent non-executive director Patrick Grasby of Drax Group PLC, an electrical power generation company, has previous experience of being on the environmental sustainability committee in OPG Power Ventures group. He is therefore encoded in our sample as an EED. On average, a firm has 1.4 EEDs. We then aggregate this indicator at the board level in three different ways. First, we use a binary indicator (EED dummy), which is equal to one if at least one director on the board is an EED. Second, to attenuate the concern that a binary measure of EED might partially capture the effect of independent directors, we examine in two alternate specifications the effect of directors with environmental knowledge using Number of EEDs on the board and Average Tenure of EEDs on the board.

It may be the case that the presence of EEDs on the board reflects a firm's intrinsic focus on environmental issues. To isolate the effect of environmental expertise, we also define an indicator for the presence of an environmental committee on the board. This measure captures the importance of environmental performance to a firm: a firm with a board committee on environmental issues is likely to attach more importance to environmental performance than firms that do not have such committees. 54\% of sample firms has an environmental committee or a board committee that is concerned with environmental sustainability in 2014. This proportion was $41 \%$ at the beginning of the sample period. To test our second hypothesis, that EEDs assigned to board committees focused on environmental issues should help the firm further reduce its emissions, we also consider an interaction term.
An econometric concern of using the environmental experience of directors is the potential bias induced by assortative sorting. Two situations are plausible. First, the demand for EEDs can be higher in firms (or industries) with higher GHG emissions. Director appointment with environmental expertise is likely to be more prevalent in high-pollution industries. Even though this could induce biased estimates, such negative assortative sorting will only reinforce the importance of environmental experience of directors. Second, and more importantly, it may be possible that the supply of EEDs is constrained for high-polluting industries, i.e., out of reputation concerns, EEDs do not accept offers from polluting firms. If so, the effect of EEDs on GHG emissions will be an artifact of this positive sorting mechanism. We aim to address this concern in several ways.

In Table 2, we present the industry breakdown of GHG emissions and aggregate supply of EEDs. There is little evidence of supply constraint of such directors in highpolluting industries like energy and industrial production: about $37.25 \%$ of all EEDs are in the energy and industrial production sectors, which represent $38.32 \%$ of the firms in our sample. The distribution of EEDs partially mitigates concerns about assortative sorting. Nevertheless, we use a 2SLS approach, where we instrument the appointment of environmental directors on a board by the aggregate supply of such directors in the same industry of the firm. This aggregate supply of EEDs in each industry is computed by summing all directors with some environmental experience and sitting on the board of firms in that industry in each year. We explain the theoretical underpinning of our exclusion restrictions in the Empirical Analysis Section.

\section{EED Networks}

As previously discussed, we use information from BoardEx to build the EED networks that shared directorship gives rise to. For each year, each individual EED is a node, and two such directors (or nodes) $i$ and $j$ are connected if they sit on at least one board $k$ in time $t$. Mathematically, a network is a square "adjacency" matrix where each cell indicates whether two individual directors are connected. As we use undirected networks whereby the connection 
Table 3 Network summary statistics

\begin{tabular}{lllllllll}
\hline & 2007 & 2008 & 2009 & 2010 & 2011 & 2012 & 2013 & 2014 \\
\hline No. of firms & 353 & 353 & 354 & 356 & 353 & 352 & 354 & 354 \\
No. of directors & 1254 & 1372 & 1029 & 1003 & 950 & 1026 & 885 & 961 \\
No. of connections & 458 & 503 & 524 & 528 & 616 & 562 & 663 & 624 \\
Mean degree & 4.224 & 4.107 & 4.403 & 4.507 & 4.632 & 4.600 & 4.141 & 4.244 \\
Mean closeness & 0.277 & 0.280 & 0.254 & 0.269 & 0.275 & 0.281 & 0.234 & 0.267 \\
Mean betweenness & 0.022 & 0.026 & 0.023 & 0.021 & 0.029 & 0.029 & 0.032 & 0.025 \\
Mean Eigen vector & 0.054 & 0.057 & 0.050 & 0.059 & 0.066 & 0.051 & 0.048 & 0.053 \\
\hline
\end{tabular}

between two directors has no directional character (i.e., there is no assumption on the direction of the flow of information between two directors), the adjacency matrix is symmetric. Note that for our baseline analysis we focus on the network of non-executive EEDs only.

Our objective is to analyze how the relative importance or centrality of EEDs in the network affects a firm's environmental performance. The concept of connections quality or centrality is multidimensional. We focus on four basic dimensions widely used in the network literature (see Jackson 2010). The degree or the number of unique connections to other EEDs gives us the number of channels of information available. Second, closeness measures how easily an EED can reach all the other EEDs in the network. A high level of closeness indicates better interactions among EEDs without going through many intermediaries. Third, any director is more central in a network if she/ he is connected to more directors. This measure, betweenness, emphasizes the role of an EED as an intermediary in a given network. Finally, an EED is well-networked if she is connected to other EEDs who are also well-networked. Eigenvector measures EED's centrality based on the centrality of her first-degree connections. Formal definitions of these centrality measures can be found in "Appendix 4".

To obtain a measure of centrality at the board-level, we compute the average centrality measures for all the EEDs on the board in a given year. In Table 3 , we provide the time series of our centrality measures at the board level. On average, an individual firm is linked to 4 other firms (Degree) and this remains stable over time. The average closeness and betweenness measures of our sample are also stable over time. Given that the time series of the aggregate network are stable, our concern that the empirical results could be an artifact of the secular increase in aggregate board network is mitigated. In Table 2, we present the industry-wise breakdown of the network centrality measures. For example, energy and pharmaceuticals sectors have the highest degree and the highest level of closeness, which means that the EEDs in these industries can more easily communicate with other directors in the network and that information could be transmitted more quickly. They also have the highest Eigenvector centrality:
EEDs in these sectors are connected to better-networked directors.

There are a few econometric issues with using network centrality measures. First, larger firms tend to have betternetworked boards (Larcker et al. 2013). We purge the firm size effects by regressing the four centrality measures on the log of firm size and the square of the log of firm size and using the residuals as size-adjusted centrality measures. Furthermore, if board centrality in the network is positively correlated with director quality, then our empirical test will simply capture the effect of better quality directors on GHG emissions. Ideally, an exogenous shock is required to establish the effect of board network on GHG emissions. However, an exogenous shock to board network that doesn't otherwise affect GHG emissions is not immediately obvious. We will discuss later our approach to address this concern.

\section{Control Variables}

Following previous works on corporate environmental performance, we use a range of firm and industry-level observables in our baseline estimates to control for confounding factors (de Villiers et al. 2011; Rao and Tilt 2016).

First, to ensure that our results are not driven by the effect of independent directors, we control for the proportion of independent non-executive directors on the board (\% NonExecutive Directors). Additionally, we control for a range of board governance variables. This includes the number of directors (Board Size), CEO duality whether the CEO is also the Chairman (CEO Duality), an indicator for the presence of a legal expert on the board (Law Expert), and the average number of years the firm's directors have served on the board (Board Tenure). We also control for the institutional shareholding of firms (\%Shareholding-Institutions) because institutional ownership is shown to be associated with better environmental performance (Johnson and Greening 1999).

Second, we control for firm characteristics that can affect environmental performance. We use firm age as a proxy for the technology that a firm has access to (Firm Age). We control for the standard set of financial measures like profitability ( $R O A$ ), firm size ( Ln Sales), and risk in the operating environment (Volatility). Following de Villiers et al. 
(2011), we also control for financial slack measured as cash or cash equivalents over total assets (Slack). To control for the capital structure of the firm, we use total debt over total equity as our measure of leverage (Leverage). Environmental performance may be affected by the investment opportunity set of a firm. For this reason, we control for market-to-book value $(M T B V)$.

Finally, because the environmental performance of a firm may be related to the industry it operates in, we control for the Herfindahl-Hirschman index as a measure of industry competitiveness $(H H I)$. The correlation matrix of the key variables is presented in Table 4.

In "Appendix 5", we also present univariate differences for all observable firm characteristics for firms with and without EEDs. The results show that firms with EEDs have larger boards, lower degree, and lower GHG emissions. However, there are no statistically significant differences in any other aspects. This partially mitigates our concerns that appointments of EEDs are non-random.

\section{Empirical Analysis}

In this section, we examine how environmental performance of firms is affected by director skills and network connections. We first present the results of a standard panel twoway fixed effects model. We then check that our findings are not driven by endogeneity in environmental performance. Finally, we analyze the impact of EEDs on other corporate outcomes.

\section{EEDs and Environmental Performance}

Our first two hypotheses are that the presence of EEDs on a board and their assignment to board environmental committees affect the environmental performance of firms. We present the results in Table 5 with robust standard errors clustered at the firm level. We estimate the following regression equation:

$G H G_{i t}=\alpha_{i}+\delta_{t}+\beta^{T} \mathbf{E x p}_{i t-1}+\gamma^{T} \mathbf{Z}_{i t}+\epsilon_{i t}$

where $i$ denotes the firm and $t$ the year. Variables are defined as follows: $G H G_{i t}$ is the total GHG emissions of firm $i$ in year $t$ (standardized by the threshold levels), $\alpha_{i}$ is the firm fixed effect, $\delta_{t}$ is the year fixed effect. Vector $\mathbf{Z}_{i t}$ contains the various firm, board and industry-level control variables discussed in the previous section.

The vector $\mathbf{E x p}_{i t-1}$ contains the variables of interest related to environmental expertise for firm $i$ in year $t-1$ : the binary variable EED dummy, which is equal to one if at least one director on the board has some environmental experience, the binary variable Environmental Committee and the interaction term. As denoted by the subscripts, environmental expertise is measured in the year preceding GHG emissions. In establishing an association between board characteristics and environmental performance (and later for network centrality and environmental performance), reverse causal associations whereby an individual director with a background in environmental sustainability accepts positions in firms with better performance need close attention. We try to mitigate this concern in the following ways. First, we lag the independent variables by one year. This identifies board characteristics that predate emissions by at least one year. Second, our baseline estimates include year and firm fixed effects. Firm fixed effects control for timeinvariant unobservable firm characteristics that might simultaneously impact upon GHG emissions and the appointment of directors with environmental expertise. Year fixed effects capture the influence of aggregate trends.

In column 1, we show that the presence of at least one director with environmental experience on the board is associated with lower GHG emissions. In column 2 , we add the indicator for the presence of an environmental committee on the board. In this specification, we are trying to isolate the effect of director expertise from the firm's intrinsic focus on environmental issues. Both director expertise and the presence of an environmental committee seem to be negatively associated with GHG emissions. The effect of board expertise on GHG emissions persists after controlling for the importance of environmental performance to the firm. In column 3, we add an interaction of board expertise in environmental issues and the presence of an environmental committee. This captures the effect of appointing a director with environmental expertise on environmental committees and allows us to test our Hypothesis 2. In addition to environmental committees and environmental expertise, the interaction term is also negatively associated with GHG emissions. Finally, as shown in columns 4 and 5, the economic and statistical significances of our results are not affected by the use of alternate measures of environmental experience of the board (i.e., number of EEDs, and Average tenure of EEDs). ${ }^{4}$

In gist, these estimates suggest that our first two hypotheses are supported. These results provide evidence that the board of directors represents the concerns of wider stakeholders of the firm, over and above their fiduciary responsibility of shareholder value maximization. Appointing EEDs on boards, and subsequently assigning them to

\footnotetext{
${ }^{4}$ As a measure of robustness, we examine the effect of executive directors with environmental expertise (executive EEDs) using a dummy variable, Executive- EEDs, defined in a similar way as EED Dummy. We find a negative and statistically significant association between executive EEDs and GHG emissions (at a level of 5\%). However, the coefficient $(-0.008)$ is lower than the coefficients for nonexecutive EEDs from columns 1-3 of Table. Full results are available upon request.
} 


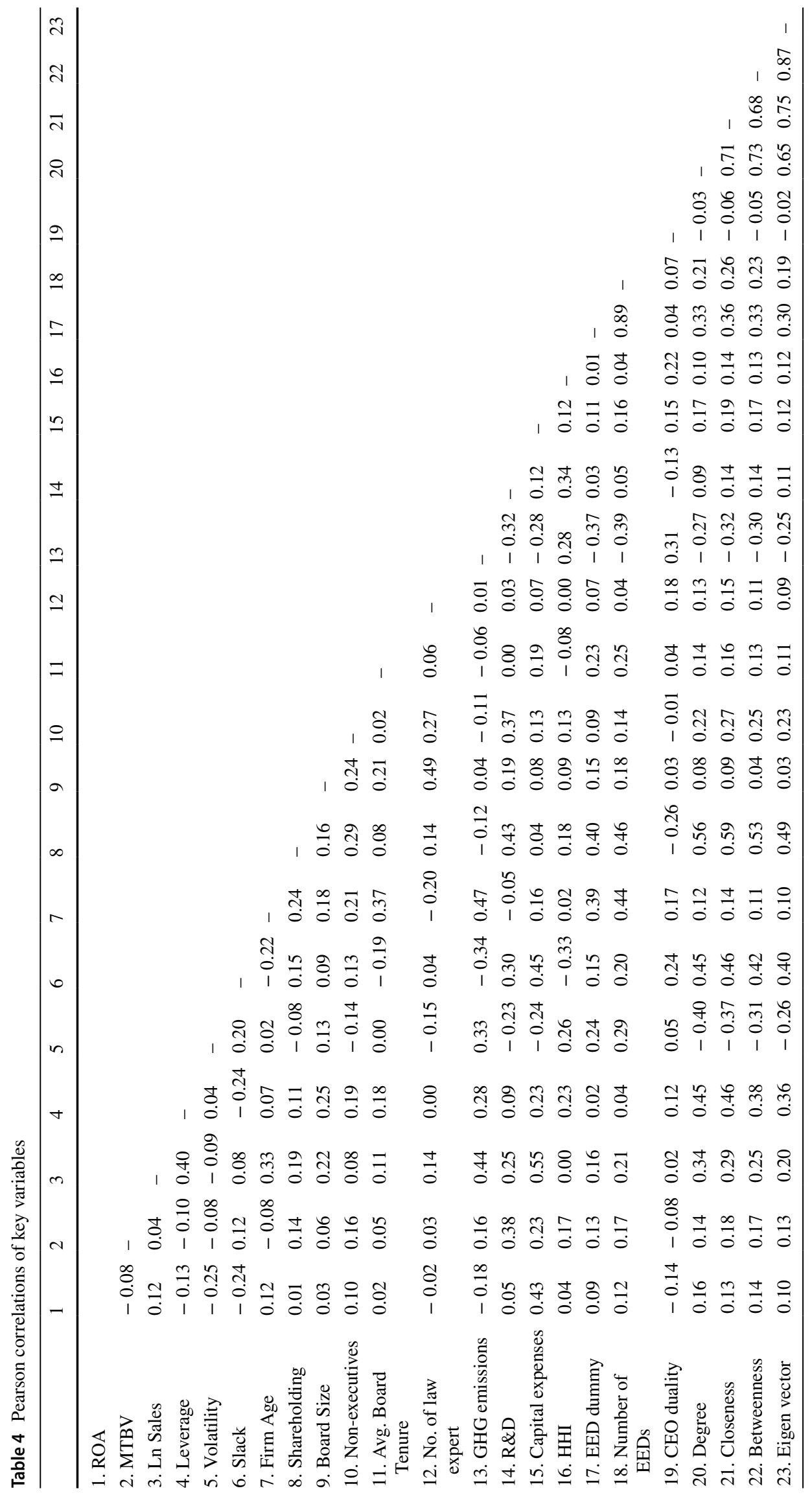


Table 5 Director experience and $\mathrm{GHG}$ emissions

\begin{tabular}{|c|c|c|c|c|c|}
\hline & \multicolumn{5}{|c|}{ Dependent variable: GHG emissions } \\
\hline & $(1)$ & (2) & (3) & (4) & $(5)$ \\
\hline EED dummy & $\begin{array}{l}-0.027 * * \\
(0.013)\end{array}$ & $\begin{array}{l}-0.021^{* *} \\
(0.009)\end{array}$ & $\begin{array}{l}-0.015^{* *} \\
(0.007)\end{array}$ & & \\
\hline Environmental Committees & & $\begin{array}{l}-0.011 * * \\
(0.004)\end{array}$ & $\begin{array}{l}-0.010 * * \\
(0.005)\end{array}$ & $\begin{array}{l}-0.014 * * \\
(0.005)\end{array}$ & $\begin{array}{l}-0.009 * * \\
(0.003)\end{array}$ \\
\hline $\begin{array}{l}\text { EED dummy * Environ- } \\
\text { mental Committees }\end{array}$ & & & $\begin{array}{l}-0.029 * * \\
(0.010)\end{array}$ & & \\
\hline Number of EEDs & & & & $\begin{array}{l}-0.049 * * \\
(0.023)\end{array}$ & \\
\hline $\begin{array}{l}\text { Number of EEDs * Environ- } \\
\text { mental Committees }\end{array}$ & & & & $\begin{array}{l}-0.023^{* *} \\
(0.008)\end{array}$ & \\
\hline Average Tenure-EEDs & & & & & $\begin{array}{l}-0.035^{* *} \\
(0.015)\end{array}$ \\
\hline $\begin{array}{l}\text { Average Tenure-EEDs*Env- } \\
\text { ironmental Committees }\end{array}$ & & & & & $\begin{array}{l}-0.018^{* *} \\
(0.007)\end{array}$ \\
\hline \%Shareholding-Institutions & $\begin{array}{l}-0.023^{* *} \\
(0.011)\end{array}$ & $\begin{array}{l}-0.016^{* *} \\
(0.008)\end{array}$ & $\begin{array}{l}-0.011^{* *} \\
(0.005)\end{array}$ & $\begin{array}{l}-0.015^{* *} \\
(0.006)\end{array}$ & $\begin{array}{l}-0.010^{* *} \\
(0.004)\end{array}$ \\
\hline Board Size & $\begin{array}{l}0.019 \\
(0.013)\end{array}$ & $\begin{array}{l}0.016 \\
(0.012)\end{array}$ & $\begin{array}{l}0.014 \\
(0.009)\end{array}$ & $\begin{array}{l}0.008 \\
(0.007)\end{array}$ & $\begin{array}{l}0.001 \\
(0.005)\end{array}$ \\
\hline$\%$ Non-executive directors & $\begin{array}{l}0.024 \\
(0.017)\end{array}$ & $\begin{array}{l}0.019 \\
(0.010)\end{array}$ & $\begin{array}{l}0.017 \\
(0.013)\end{array}$ & $\begin{array}{l}0.002 \\
(0.005)\end{array}$ & $\begin{array}{l}0.003 \\
(0.003)\end{array}$ \\
\hline Average Board Tenure & $\begin{array}{l}0.000 \\
(0.001)\end{array}$ & $\begin{array}{l}0.001 \\
(0.002)\end{array}$ & $\begin{array}{l}0.000 \\
(0.000)\end{array}$ & $\begin{array}{l}0.000 \\
(0.000)\end{array}$ & \\
\hline Law Expert & $\begin{array}{l}0.122 \\
(0.134)\end{array}$ & $\begin{array}{l}0.128 \\
(0.130)\end{array}$ & $\begin{array}{l}0.110 \\
(0.125)\end{array}$ & $\begin{array}{l}0.093 \\
(0.106)\end{array}$ & $\begin{array}{l}0.066 \\
(0.091)\end{array}$ \\
\hline Ln Sales & $\begin{array}{l}0.016^{*} \\
(0.008)\end{array}$ & $\begin{array}{l}0.012 \\
(0.009)\end{array}$ & $\begin{array}{l}0.013 \\
(0.010)\end{array}$ & $\begin{array}{l}0.015 \\
(0.010)\end{array}$ & $\begin{array}{l}0.017 \\
(0.013)\end{array}$ \\
\hline ROA & $\begin{array}{l}0.004 \\
(0.003)\end{array}$ & $\begin{array}{l}0.006 \\
(0.005)\end{array}$ & $\begin{array}{l}0.001 \\
(0.003)\end{array}$ & $\begin{array}{l}0.008 \\
(0.006)\end{array}$ & $\begin{array}{l}0.003 \\
(0.004)\end{array}$ \\
\hline MTBV & $\begin{array}{l}-0.009 \\
(0.008)\end{array}$ & $\begin{array}{l}-0.013 \\
(0.008)\end{array}$ & $\begin{array}{l}-0.011 \\
(0.012)\end{array}$ & $\begin{array}{l}-0.017 \\
(0.010)\end{array}$ & $\begin{array}{l}-0.012 \\
(0.009)\end{array}$ \\
\hline Leverage & $\begin{array}{l}-0.004 \\
(0.008)\end{array}$ & $\begin{array}{l}-0.000 \\
(0.002)\end{array}$ & $\begin{array}{l}-0.001 \\
(0.002)\end{array}$ & $\begin{array}{l}-0.003 \\
(0.003)\end{array}$ & $\begin{array}{l}-0.001 \\
(0.003)\end{array}$ \\
\hline Slack & $\begin{array}{l}-0.002 \\
(0.002)\end{array}$ & $\begin{array}{l}-0.004 * * \\
(0.002)\end{array}$ & $\begin{array}{l}-0.002 * * \\
(0.001)\end{array}$ & $\begin{array}{l}-0.005^{* *} \\
(0.002)\end{array}$ & $\begin{array}{l}-0.003 * \\
(0.002)\end{array}$ \\
\hline Volatility & $\begin{array}{l}0.008 \\
(0.013)\end{array}$ & $\begin{array}{l}0.006 \\
(0.009)\end{array}$ & $\begin{array}{l}0.006 \\
(0.008)\end{array}$ & $\begin{array}{l}0.003 \\
(0.004)\end{array}$ & $\begin{array}{l}0.004 \\
(0.004)\end{array}$ \\
\hline CEO Duality & $\begin{array}{l}0.134 \\
(0.122)\end{array}$ & $\begin{array}{l}0.139 \\
(0.129)\end{array}$ & $\begin{array}{l}0.138 \\
(0.116)\end{array}$ & $\begin{array}{l}0.144 \\
(0.120)\end{array}$ & $\begin{array}{l}0.139 \\
(0.115)\end{array}$ \\
\hline Firm Age & $\begin{array}{l}0.013 \\
(0.010)\end{array}$ & $\begin{array}{l}0.010 \\
(0.007)\end{array}$ & $\begin{array}{l}0.011 \\
(0.011)\end{array}$ & $\begin{array}{l}0.017 \\
(0.016)\end{array}$ & $\begin{array}{l}0.013 \\
(0.010)\end{array}$ \\
\hline HHI & $\begin{array}{l}-0.123 \\
(0.104)\end{array}$ & $\begin{array}{l}0.120 \\
(0.100)\end{array}$ & $\begin{array}{l}0.120 \\
(0.108)\end{array}$ & $\begin{array}{l}0.131 \\
(0.115)\end{array}$ & $\begin{array}{l}0.118 \\
(0.103)\end{array}$ \\
\hline Year dummies & Yes & Yes & Yes & Yes & Yes \\
\hline Firm fixed effects & Yes & Yes & Yes & Yes & Yes \\
\hline Constant & $\begin{array}{l}0.214 * * * \\
(0.030)\end{array}$ & $\begin{array}{l}0.202 * * * \\
(0.035)\end{array}$ & $\begin{array}{l}0.187 * * * \\
(0.046)\end{array}$ & $\begin{array}{l}0.224 * * * \\
(0.040)\end{array}$ & $\begin{array}{l}0.206 * * * \\
(0.065)\end{array}$ \\
\hline Observations & 3244 & 3244 & 3244 & 3244 & 3244 \\
\hline Adjusted- $R^{2}$ & 0.247 & 0.253 & 0.259 & 0.242 & 0.194 \\
\hline
\end{tabular}

Robust standard errors, clustered at the firm level are in brackets

$* p<0.10, * * p<0.05, * * * p<0.01$ 
environmental committees, is indicative of substantive environmental actions. This is evident in better environmental performance in terms of reduced GHG emissions. To quantify, a one-standard-deviation increase in the number of EEDs on the board is associated with a decrease in GHG emissions by 0.004 standard deviation. This implies that over 6 years, i.e., the average tenure of EEDs, the decrease in GHG emissions will be roughly 0.024 standard deviations. This is equivalent to a reduction of 56,000 tonnes of $\mathrm{CO}_{2}$ equivalent for an average firm. The economic effect of EED appointment on GHG emissions is likely to be small because GHG emissions trade-off environmental sustainability and productive capacity. Moreover, due to the long-term nature of some environmental investments, the reduction in GHG emissions will probably be realized over a longer time period.

In addition to specific skills related to environmental sustainability, EEDs can facilitate the exchange of information on environmental technologies across different firms (Hypothesis 3). We investigate the effect of network connections of EEDs on GHG emissions by estimating Eq. (1) augmented with a measure of network centrality:

$\mathrm{GHG}_{i t}=\alpha_{i}+\delta_{t}+\beta_{1} \mathbf{E x p}_{i t-1}+\beta_{2}$ Network $_{i t-1}+\gamma^{T} \mathbf{Z}_{i t}+\epsilon_{i t}$

where the variable Network ${ }_{i t-1}$ is one of the four centrality measures previously defined for firm $i$ in year $t-1$ : degree, closeness, betweenness, and eigenvector. As explained before, we use size-adjusted centrality measures in all our specifications and lag the independent variables by one year. ${ }^{5}$ We present the results in Table 6 with robust standard errors clustered at the firm level. In all the specifications, we also control for the presence of EEDs (using EED dummy). We find that controlling for specific environmental skills of directors, the network centrality of these directors has additional explanatory power for GHG emissions. All measures of centrality are negatively associated with GHG emissions, and such associations are statistically significant, except for the Degree. This is consistent with the resource dependence theory and tends to support our third hypothesis. The argument of value-destroying practices propagated through director networks does not seem to hold here. Director networks seem to improve a firm's ethical practices.

The degree is the number of other directors an EED is connected with (or the number of information channels), while the other centrality measures are different proxies of the quality of these information channels. Our findings suggest that the quality rather than the number of connections

\footnotetext{
5 The reason why we dot include all the centrality measures in the same regression but add them one at a time is that they are highly correlated.
}

between EEDs matters for environmental performance. An increase in the level of closeness implies that an EED will need fewer intermediaries to reach all the other boards in the network and so it will have a quicker access to the information available in other firms. An increase in the betweenness means that an EED will more often stand between pairs of boards in the network and will have a greater control over the information passing between these pairs. An increase in the eigenvector centrality measures implies that an EED is connected to more important boards with potentially many connections and more information channels. Like with appointments of EEDs, even though it is economically significant, the real effect of EED networks on GHG emissions is likely to be small. To quantify, a one-standard-deviation increase in the network centrality of EEDs on the board (measured by closeness) is associated with a decrease in GHG emissions by $0.233 \times 10^{-4}$ standard deviation. This implies that over 6 years, i.e., the average tenure of EEDs, the decrease in GHG emissions will be roughly 0.00014 of a standard deviation. This is equivalent to a reduction of 39 tonnes of $\mathrm{CO}_{2}$ equivalent. Again, it is very likely that given the statistical significance of our estimates, these GHG reductions will be realized over a longer time period.

Results from Tables 5 and 6 shed light on how some governance mechanisms can affect a firm's ethical behavior. We show that director expertise and network help the firm implement substantive ethical practices that improve its environmental performance (in terms of GHG emissions). Our findings also suggest that the advisory role of directors through information provision is a key element in a firm's ethical behavior. From Tables 5 and 6, the two channels of information agglomeration seem to matter for firms' environmental performance. First, specific skills of directors in environmental sustainability facilitate their advisory capacity and seem to improve environmental performance, especially if these EEDs are also sitting on board environmental committees (Hypotheses 1 and 2). At the same time, these directors' better access to information regarding good environmental practices through board networks also positively influences environmental performance (Hypothesis 3 ). These results indicate that, notwithstanding the potential for collusion, the professional network of directors helps in the propagation of ethical and sustainable practices.

\section{Endogenous EED Appointment and Network Formation}

There are a few remaining econometric concerns. First, appointments of EEDs can be driven by time-varying unobservable characteristics or shocks. For example, it could be possible that appointment of directors with environmental expertise happens around other major changes in the firms. Only $13 \%$ of CEO turnovers and $7 \%$ of M\&As coincide 
Table 6 EED networks and GHG emissions

\begin{tabular}{|c|c|c|c|c|}
\hline & \multicolumn{4}{|c|}{ Dependent variable: GHG emissions } \\
\hline & (1) & (2) & (3) & (4) \\
\hline Degree & $\begin{array}{l}-0.018 \\
(0.013)\end{array}$ & & & \\
\hline Closeness & & $\begin{array}{l}-0.038^{* *} \\
(0.018)\end{array}$ & & \\
\hline Betweenness & & & $\begin{array}{l}-0.029 * * \\
(0.013)\end{array}$ & \\
\hline Eigen vector & & & & $\begin{array}{l}-0.009 * * \\
(0.003)\end{array}$ \\
\hline EED dummy & $\begin{array}{l}-0.029 * * \\
(0.012)\end{array}$ & $\begin{array}{l}-0.023^{* *} \\
(0.010)\end{array}$ & $\begin{array}{l}-0.017 * * \\
(0.008)\end{array}$ & $\begin{array}{l}-0.020^{* * *} \\
(0.009)\end{array}$ \\
\hline$\%$ Shareholding-Institutions & $\begin{array}{l}-0.020^{* *} \\
(0.008)\end{array}$ & $\begin{array}{l}-0.019 * * \\
(0.008)\end{array}$ & $\begin{array}{l}-0.017 \text { ** } \\
(0.007)\end{array}$ & $\begin{array}{l}-0.0012 * * \\
(0.006)\end{array}$ \\
\hline Board Size & $\begin{array}{l}0.013 \\
(0.009)\end{array}$ & $\begin{array}{l}0.014 \\
(0.008)\end{array}$ & $\begin{array}{l}0.011 \\
(0.009)\end{array}$ & $\begin{array}{l}0.013 \\
(0.009)\end{array}$ \\
\hline$\%$ Non-executive directors & $\begin{array}{l}0.023 \\
(0.012)\end{array}$ & $\begin{array}{l}0.025 \\
(0.015)\end{array}$ & $\begin{array}{l}0.024 \\
(0.015)\end{array}$ & $\begin{array}{l}0.026 \\
(0.018)\end{array}$ \\
\hline Average board tenure & $\begin{array}{l}0.000 \\
(0.001)\end{array}$ & $\begin{array}{l}0.000 \\
(0.001)\end{array}$ & $\begin{array}{l}0.002 \\
(0.003)\end{array}$ & $\begin{array}{l}0.000 \\
(0.000)\end{array}$ \\
\hline Law expert & $\begin{array}{l}0.119 \\
(0.130)\end{array}$ & $\begin{array}{l}0.124 \\
(0.129)\end{array}$ & $\begin{array}{l}0.113 \\
(0.128)\end{array}$ & $\begin{array}{l}0.105 \\
(0.116)\end{array}$ \\
\hline Ln Sales & $\begin{array}{l}0.018^{*} \\
(0.010)\end{array}$ & $\begin{array}{l}0.014 * \\
(0.007)\end{array}$ & $\begin{array}{l}0.012 * \\
(0.007)\end{array}$ & $\begin{array}{l}0.018^{*} \\
(0.009)\end{array}$ \\
\hline ROA & $\begin{array}{l}0.006 \\
(0.004)\end{array}$ & $\begin{array}{l}0.002 \\
(0.002)\end{array}$ & $\begin{array}{l}0.004 \\
(0.003)\end{array}$ & $\begin{array}{l}0.004 \\
(0.004)\end{array}$ \\
\hline MTBV & $\begin{array}{l}-0.008 \\
(0.008)\end{array}$ & $\begin{array}{l}-0.013 \\
(0.009)\end{array}$ & $\begin{array}{l}-0.010 \\
(0.011)\end{array}$ & $\begin{array}{l}-0.017 \\
(0.013)\end{array}$ \\
\hline Leverage & $\begin{array}{l}-0.009 \\
(0.009)\end{array}$ & $\begin{array}{l}-0.008 \\
(0.008)\end{array}$ & $\begin{array}{l}-0.002 \\
(0.002)\end{array}$ & $\begin{array}{l}-0.000 \\
(0.002)\end{array}$ \\
\hline Slack & $\begin{array}{l}-0.002 \\
(0.002)\end{array}$ & $\begin{array}{l}-0.003 * * \\
(0.001)\end{array}$ & $\begin{array}{l}-0.002^{* *} \\
(0.001)\end{array}$ & $\begin{array}{l}-0.004 * * \\
(0.002)\end{array}$ \\
\hline Volatility & $\begin{array}{l}0.009 \\
(0.019)\end{array}$ & $\begin{array}{l}0.006 \\
(0.015)\end{array}$ & $\begin{array}{l}0.006 \\
(0.009)\end{array}$ & $\begin{array}{l}0.006 \\
(0.009)\end{array}$ \\
\hline $\mathrm{R} \& \mathrm{D}$ & $\begin{array}{l}-0.017 \\
(0.015)\end{array}$ & $\begin{array}{l}-0.017 \\
(0.020)\end{array}$ & $\begin{array}{l}-0.013 \\
(0.014)\end{array}$ & $\begin{array}{l}-0.014 \\
(0.016)\end{array}$ \\
\hline CEO duality & $\begin{array}{l}0.130 \\
(0.122)\end{array}$ & $\begin{array}{l}0.122 \\
(0.128)\end{array}$ & $\begin{array}{l}0.129 \\
(0.125)\end{array}$ & $\begin{array}{l}0.140 \\
(0.126)\end{array}$ \\
\hline HHI & $\begin{array}{l}0.127 \\
(0.110)\end{array}$ & $\begin{array}{l}-0.122 \\
(0.108)\end{array}$ & $\begin{array}{l}0.117 \\
(0.102)\end{array}$ & $\begin{array}{l}0.118 \\
(0.111)\end{array}$ \\
\hline Firm Age & $\begin{array}{l}0.011 \\
(0.011)\end{array}$ & $\begin{array}{l}0.009 \\
(0.010)\end{array}$ & $\begin{array}{l}0.013 \\
(0.009)\end{array}$ & $\begin{array}{l}0.011 \\
(0.009)\end{array}$ \\
\hline Year dummies & Yes & Yes & Yes & Yes \\
\hline Firm fixed effects & Yes & Yes & Yes & Yes \\
\hline Constant & $\begin{array}{l}0.165 * * * \\
(0.025)\end{array}$ & $\begin{array}{l}0.154 * * * \\
(0.028)\end{array}$ & $\begin{array}{l}0.133 * * * \\
(0.041)\end{array}$ & $\begin{array}{l}0.148 * * * \\
(0.033)\end{array}$ \\
\hline Observations & 3244 & 3244 & 3244 & 3244 \\
\hline Adjusted- $R^{2}$ & 0.344 & 0.379 & 0.395 & 0.381 \\
\hline
\end{tabular}

Robust standard errors, clustered at the firm level are in brackets $* p<0.10, * * p<0.05, * * * p<0.01$ with the change in firms' status of having an environmental director or not. This partially addresses the concern that unobserved shocks are changing both GHG emissions and the appointment of environmental directors. Second, the presence of EEDs on boards can be sticky at the firm level over time. We find in our sample, 77,72 and $70 \%$ of the firms that had at least one EED in period $t$ also have them in periods $t+1, t+2, t+3$ respectively. It has been argued that 
Table 7 Controlling for endogeneity in director experience and GHG

\begin{tabular}{|c|c|c|c|c|}
\hline & \multicolumn{4}{|c|}{ Dependent variables } \\
\hline & \multirow{2}{*}{$\begin{array}{l}\text { EED } \\
\text { (1) }\end{array}$} & \multicolumn{3}{|c|}{ GHG emissions } \\
\hline & & (2) & (3) & (4) \\
\hline Ln (Supply per seat) & $\begin{array}{l}0.281 * * * \\
(0.079)\end{array}$ & & & \\
\hline EED dummy & & $\begin{array}{l}-0.022^{* *} \\
(0.011)\end{array}$ & $\begin{array}{l}-0.021 * * \\
(0.009)\end{array}$ & $\begin{array}{l}-0.015^{* *} \\
(0.007)\end{array}$ \\
\hline Environmental Committees & & & $\begin{array}{l}-0.011^{* *} \\
(0.004)\end{array}$ & $\begin{array}{l}-0.010^{* *} \\
(0.005)\end{array}$ \\
\hline $\begin{array}{l}\text { EED * Environmental } \\
\text { committees }\end{array}$ & & & & $\begin{array}{l}-0.029 * * \\
(0.010)\end{array}$ \\
\hline Control variables & Yes & Yes & Yes & Yes \\
\hline Year dummies & Yes & Yes & Yes & Yes \\
\hline Firm fixed effects & Yes & Yes & Yes & Yes \\
\hline Constant & $\begin{array}{l}0.221 * * * \\
(0.033)\end{array}$ & $\begin{array}{l}0.223 * * * \\
(0.060)\end{array}$ & $\begin{array}{l}0.218 * * * \\
(0.041)\end{array}$ & $\begin{array}{l}0.206 * * * \\
(0.059)\end{array}$ \\
\hline First stage $F$-Statistic & 12.65 & & & \\
\hline Observations & 3244 & 3244 & 3244 & 3244 \\
\hline Adjusted- $R^{2}$ & 0.231 & 0.237 & 0.240 & 0.249 \\
\hline
\end{tabular}

Robust standard errors clustered at the firm level are in brackets

$* p<0.10, * * p<0.05, * * * p<0.01$ in cases of time-persistent regressors, instrumental variables regressions are preferred over fixed effects models (Angrist and Pischke 2008; Dass et al. 2014).

To address these two issues and ensure that the baseline results presented above are not driven by endogeneity in environmental performance, we estimate an IV-regression where we use the supply of EEDs at the industry level as an exogenous source of variation in the firm-level appointment of such directors. Our instrument is Ln(industry supply of environmental directors per seat). Using a measure of industry supply as the exclusion restriction relies on the assumption that firms appoint directors with environmental expertise from within the same industry to leverage industry-specific knowledge. ${ }^{6}$ This is based on a few established results in corporate finance. First, Knyazeva et al. (2013) show that director labor market is highly localized. As industries tend to be geographically localized, we measure the supply of EEDs by identifying and summing all EEDs in every 2-digit SIC codes. This relatively broad definition of an industry is based on a second result: outside directors are more likely to have executive experience in other firms at the time of appointment but are less likely to be from a firm's direct competitor (Linck et al. 2008). This industry supply is then scaled by the aggregate board size in the same

\footnotetext{
${ }^{6}$ If this assumption is relaxed, and environmental directors are appointed from across industry classifications, the instrument will lack power in the first-stage estimates.
}

industry to implicitly control for industry effects. The theoretical underpinning of this approach is that if the supply of EEDs in the industry increases, a greater supply of EEDs is likely to reduce the search cost for such appointments, but it doesn't directly impact upon GHG emissions at the firm level.

We present the 2SLS results in Table 7 for the just identified models. This is essentially a Heckman-type selection model where the dependent variable in the first stage is the binary indicator EED. First, we check that the instrument is relevant in the first-stage regression, which is presented in column 1 . The instrument is positively associated with the board expertise in environmental affairs, and this association is statistically significant. Further, the F-statistics of the first-stage regression is greater than 10 , thereby mitigating concerns about the weak instrument. We present the second stage results in columns $2-4$ with heteroscedasticity robust standard errors. The parameter estimates of board expertise in environmental issues are negative and are statistically significant. Our result that environmental expertise matters for ethical behavior does not seem to be driven by the potential endogenous selection of EEDs to boards. ${ }^{7}$

\footnotetext{
7 An alternative empirical strategy would be to look at new director appointments and subsequent environmental performance. This can, however, be potentially endogenous because firms can appoint EEDs precisely because they are trying to respond to environmental concerns.
} 
Table 8 Controlling for endogeneity in board network and GHG emissions

\begin{tabular}{|c|c|c|c|c|c|}
\hline & \multicolumn{5}{|c|}{ Dependent variable: GHG emissions } \\
\hline & (1) & (2) & (3) & (4) & (5) \\
\hline \multicolumn{6}{|c|}{ Panel A: Regressions with unchanged board sample } \\
\hline Degree & $\begin{array}{l}-0.017 \\
(0.014)\end{array}$ & & & & \\
\hline Closeness & & $\begin{array}{l}-0.035^{* *} \\
(0.018)\end{array}$ & & & \\
\hline Betweenness & & & $\begin{array}{l}-0.020^{* *} \\
(0.010)\end{array}$ & & \\
\hline Eigen vector & & & & $\begin{array}{l}-0.009^{*} \\
(0.005)\end{array}$ & \\
\hline EED dummy & & & & & $\begin{array}{l}-0.011^{* *} \\
(0.005)\end{array}$ \\
\hline Environmental Committees & & & & & $\begin{array}{l}-0.009 * * \\
(0.004)\end{array}$ \\
\hline EED *Environmental Committees & & & & & $\begin{array}{l}-0.023^{* *} \\
(0.011)\end{array}$ \\
\hline Firm covariates & Yes & Yes & Yes & Yes & Yes \\
\hline Year dummies & Yes & Yes & Yes & Yes & Yes \\
\hline Firm fixed effects & Yes & Yes & Yes & Yes & Yes \\
\hline Constant & $\begin{array}{l}0.191 * * * \\
(0.044)\end{array}$ & $\begin{array}{l}0.197 * * * \\
(0.039)\end{array}$ & $\begin{array}{l}0.186 * * * \\
(0.051)\end{array}$ & $\begin{array}{l}0.194 * * * \\
(0.047)\end{array}$ & $\begin{array}{l}0.207 * * * \\
(0.033)\end{array}$ \\
\hline Observations & 1404 & 1404 & 1404 & 1404 & 1404 \\
\hline Adjusted- $R^{2}$ & 0.131 & 0.166 & 0.158 & 0.160 & 0.164 \\
\hline \multicolumn{6}{|c|}{ Panel B: Regressions with unchanged board and first-degree links Sample } \\
\hline Degree & $\begin{array}{l}-0.019 \\
(0.013)\end{array}$ & & & & \\
\hline Closeness & & $\begin{array}{l}-0.041 * * \\
(0.20)\end{array}$ & & & \\
\hline Betweenness & & & $\begin{array}{l}-0.036^{* *} \\
(0.012)\end{array}$ & & \\
\hline Eigen Vector & & & & $\begin{array}{l}-0.017^{* *} \\
(0.008)\end{array}$ & \\
\hline EED dummy & & & & & $\begin{array}{l}-0.017 * * \\
(0.005)\end{array}$ \\
\hline Environmental Committees & & & & & $\begin{array}{l}-0.012 * * \\
(0.004)\end{array}$ \\
\hline $\begin{array}{l}\text { EED* } \\
\text { Environmental Committees }\end{array}$ & & & & & $\begin{array}{l}-0.035^{* *} \\
(0.016)\end{array}$ \\
\hline Firm covariates & Yes & Yes & Yes & Yes & Yes \\
\hline Year dummies & Yes & Yes & Yes & Yes & Yes \\
\hline Firm fixed effects & Yes & Yes & Yes & Yes & Yes \\
\hline Constant & $\begin{array}{l}0.152 * * * \\
(0.061)\end{array}$ & $\begin{array}{l}0.158 * * * \\
(0.057)\end{array}$ & $\begin{array}{l}0.147 * * * \\
(0.063)\end{array}$ & $\begin{array}{l}0.150 * * * \\
(0.072)\end{array}$ & $\begin{array}{l}0.203 * * * \\
(0.063)\end{array}$ \\
\hline Observations & 1127 & 1127 & 1127 & 1127 & 1127 \\
\hline Adjusted- $R^{2}$ & 0.137 & 0.161 & 0.152 & 0.165 & 0.163 \\
\hline
\end{tabular}

Robust standard errors clustered at the firm level are in brackets.

$* p<0.10, * * p<0.05, * * * p<0.01$
Our second concern is related to the endogenous formation of director networks and the correlation between financial performance and environmental performance. Indeed, if director quality is positively associated with the size of her network (Masulis and Mobbs 2011), more successful firms (i.e., with better financial performance and also better environmental performance if these are correlated) may attract better directors, who are also those with a larger network. The estimated coefficients of the centrality measures will then be biased. In this section, 
we perform two tests to examine the likelihood that our results are driven by such associations between quality and network size.

To begin with, we reduce our analysis to a subset of firms whose board composition did not change from the previous year. This restricts the possibility of assortative sorting because the identity (and so the quality) of the directors on the board is the same. However, their network centrality will vary because they may sit on additional boards or through changes in board composition of other firms in the network. The results for the sample with this restriction are presented in panel A of Table 8. Second, we further restrict our sample to firms whose board composition as well as first-degree network connections did not change from $t-1$ to $t$ (the EEDs in this board are sitting on the same number of boards in times $t-1$ and $t$ ). Any change in the board centrality measures (closeness, betweenness, and eigenvector) is likely to be caused only by changes in the compositions of other boards. Results with these restrictions are presented in panel B of Table 8 . The results remain economically significant but vary in statistical significance due to smaller sample size.

While we cannot establish a causal link, these results also provide additional support to our hypothesis that director networks affect GHG through EEDs better access to information. In panel A, we report the negative association of better-networked EEDs with GHG emissions in a sample of unchanged board composition. In this sample, any variation in the centrality of the focal firm is caused by changes in the first-degree connections or in the composition of other boards. Additional first-degree connections are likely to simultaneously introduce better information and better monitoring of the EEDs sitting on the focal board: by sitting on a larger number of boards, these directors' actions are exposed to more peers; and this may have a positive impact on environmental performance. In panel B, we use a further restriction of unchanged first-degree connections. This allows us to observe variations in the centrality of the focal firm caused only by variations in second-degree connections. Changes in second-degree connections are likely to improve the access to information, but may not have a direct effect on the monitoring of the focal firm. Indeed, the EEDs on the board of the focal firm is the same (unchanged board composition) and they are sitting on the same number of boards (i.e., they are connected to the same directors), but the other boards in the network may be better-connected. An increase in the centrality measures of other boards may also increase the centrality measures of the EEDs on the focal board, which can be interpreted as an increase in the quality of their connections, and so a better access to information. More broadly, this suggests that governance mechanisms enabling a better access to information may improve some corporate ethical practices.

\section{EEDs and Other Corporate Policies}

In this section, we present a range of placebo tests to analyze the effect of EEDs on other corporate outcomes. In particular, we are interested in investigating whether the EEDs affect environmental performance through their specific skills, or if these environmental skills capture the impact of some generic skills, which affect other firm outcomes as well. The underlying idea is to examine whether the appointment of EEDs reflects the desire of firms to address sustainability issues or is it simply a by-product of other financial benefits that the EEDs might contribute toward. Specifically, we examine the effects of EEDs on CEO pay and CEO turnover. This is because non-executive directors have been shown to have an impact on the monitoring role of the board. We also examine the effect of EEDs and their networks on long-term investments.

\section{CEO Pay}

To attenuate the concern that our measure of EED captures the effect of board independence, we estimate the effect of EEDs and EEDs centrality on the log of CEO pay, controlling for financial and governance characteristics. Stylized results from the corporate governance literature show that board structure affects CEO pay (Chhaochharia and Grinstein 2009; Boyd 1994). It is not immediately apparent how the presence of directors with specific environmental expertise can directly affect CEO compensation. On the other hand, if these directors are appointed for generic skills as independent directors (and environmental expertise happens to be a subset of these generic skills) then better monitoring from the board can lead to lower CEO pay. Network connections of EEDs can also affect CEO pay because a better-networked board has access to better soft information in setting CEO compensation.

The results are reported in Table 9 for EED dummy and the four measures of network centrality in columns (1)-(4), all including firm fixed effects. The coefficients of the EED dummy and the centrality measures are not statistically significant at conventional levels in any of the four specifications. Therefore, it does not seem that firms with EEDs and better-networked EEDs have significantly different levels of CEO pay compared to firms without.

\section{CEO Turnover}

Board structure and independence have been shown to affect CEO turnover (Guo and Masulis 2015; Weisbach 1988). Again, to mitigate the concern that our measure of EED captures the effect of board independence, we also study how the presence of EEDs and their centrality in the EED network affect the dismissal of poorly performing CEOs. 
Table 9 EEDs and other corporate outcomes

\begin{tabular}{|c|c|c|c|c|c|c|c|c|}
\hline & \multicolumn{4}{|l|}{ Panel A } & \multicolumn{4}{|l|}{ Panel B } \\
\hline & \multicolumn{4}{|l|}{ CEO pay } & \multicolumn{4}{|c|}{ CEO turnover } \\
\hline & (1) & (2) & (3) & (4) & $\overline{(1)}$ & (2) & (3) & (4) \\
\hline EED dummy & $\begin{array}{l}0.008 \\
(0.009)\end{array}$ & $\begin{array}{l}0.011 \\
(0.013)\end{array}$ & $\begin{array}{l}0.013 \\
(0.015)\end{array}$ & $\begin{array}{l}0.010 \\
(0.009)\end{array}$ & $\begin{array}{l}0.012 \\
(0.011)\end{array}$ & $\begin{array}{l}0.018 \\
(0.018)\end{array}$ & $\begin{array}{l}0.016 \\
(0.0014)\end{array}$ & $\begin{array}{l}0.013 \\
(0.015)\end{array}$ \\
\hline Degree & $\begin{array}{l}0.000 \\
(0.000)\end{array}$ & & & & $\begin{array}{l}0.003 \\
(0.005)\end{array}$ & & & \\
\hline Closeness & & $\begin{array}{l}0.004 \\
(0.004)\end{array}$ & & & & $\begin{array}{l}0.013 \\
(0.009)\end{array}$ & & \\
\hline Betweenness & & & $\begin{array}{l}0.007 \\
(0.005)\end{array}$ & & & & $\begin{array}{l}0.008 \\
(0.006)\end{array}$ & \\
\hline Eigen vector & & & & $\begin{array}{l}0.003 \\
(0.004)\end{array}$ & & & & $\begin{array}{l}0.010 \\
(0.009)\end{array}$ \\
\hline Firm covariates & Yes & Yes & Yes & Yes & Yes & Yes & Yes & Yes \\
\hline Year dummies & Yes & Yes & Yes & Yes & Yes & Yes & Yes & Yes \\
\hline Firm fixed effects & Yes & Yes & Yes & Yes & Yes & Yes & Yes & Yes \\
\hline Observations & 3244 & 3244 & 3244 & 3244 & 3244 & 3244 & 3244 & 3244 \\
\hline \multirow[t]{4}{*}{ Adjusted $R^{2}$} & 0.112 & 0.124 & 0.128 & 0.126 & 0.108 & 0.119 & 0.116 & 0.125 \\
\hline & \multicolumn{4}{|l|}{ Panel C } & \multicolumn{4}{|l|}{ Panel D } \\
\hline & \multicolumn{4}{|l|}{$\mathrm{R} \& \mathrm{D}$} & \multicolumn{4}{|c|}{ Capital expense } \\
\hline & (1) & (2) & (3) & (4) & (1) & (2) & (3) & (4) \\
\hline EED dummy & $\begin{array}{l}0.006 * * \\
(0.002)\end{array}$ & $\begin{array}{l}0.014 * * \\
(0.006)\end{array}$ & $\begin{array}{l}0.015^{* *} \\
(0.005)\end{array}$ & $\begin{array}{l}0.011 * * \\
(0.005)\end{array}$ & $\begin{array}{l}0.015 * * \\
(0.004)\end{array}$ & $\begin{array}{l}0.029 * * \\
(0.014)\end{array}$ & $\begin{array}{l}0.034 * * \\
(0.016)\end{array}$ & $\begin{array}{l}0.021 * * \\
(0.010)\end{array}$ \\
\hline Degree & $\begin{array}{l}0.002 \\
(0.003)\end{array}$ & & & & $\begin{array}{l}0.005 \\
(0.004)\end{array}$ & & & \\
\hline Closeness & & $\begin{array}{l}0.012 * * \\
(0.005)\end{array}$ & & & & $\begin{array}{l}0.004 * * \\
(0.002)\end{array}$ & & \\
\hline Betweenness & & & $\begin{array}{l}0.010 * * \\
(0.005)\end{array}$ & & & & $\begin{array}{l}0.005^{* *} \\
(0.002)\end{array}$ & \\
\hline Eigen vector & & & & $\begin{array}{l}0.017 * * \\
(0.008)\end{array}$ & & & & $\begin{array}{l}0.006^{* *} \\
(0.003)\end{array}$ \\
\hline Control variables & Yes & Yes & Yes & Yes & Yes & Yes & Yes & Yes \\
\hline Year dummies & Yes & Yes & Yes & Yes & Yes & Yes & Yes & Yes \\
\hline Firm fixed effects & Yes & Yes & Yes & Yes & Yes & Yes & Yes & Yes \\
\hline Observations & 3244 & 3244 & 3244 & 3244 & 3244 & 3244 & 3244 & 3244 \\
\hline Adjusted $R^{2}$ & 0.156 & 0.194 & 0.202 & 0.196 & 0.163 & 0.181 & 0.190 & 0.185 \\
\hline
\end{tabular}

Robust standard errors clustered at the firm level are in brackets

$* p<0.10, * * p<0.05, * * * p<0.01$

Using information from BoardEx, we identify all cases of CEO turnover where the executive designated as CEO in $t$ is different from that in $t-1$. We exclude CEO turnover events that are within one year of the merger, acquisition, spin-off, and major corporate restructuring. We also exclude interim-CEOs and joint-CEOs from our analysis. Finally, if the age of the CEO is less than 60 years at the time of turnover, and if she/he does not appear as a CEO/Chairman in a comparable firm within 2 years, ${ }^{8}$ we classify these events as forced turnovers. In panel B of Table 9, we present the probit results for CEO turnovers. ${ }^{9}$ There does not seem to exist a statistically significant difference in the likelihood of

\footnotetext{
${ }^{8}$ We consider a role to be comparable if the CEO becomes a CEO/ Chairman of a firm which is in the same size decile as the previous firm.

9 The results are qualitatively similar for forced CEO turnover, and are available on request.
} 
CEO turnover for firms with and without EEDs. In addition, we find no statistically significant effect of EED centrality measures on CEO turnover. Together, these results reinforce the resource provision role of the EEDs.

\section{Research and Development and Capital Expenses}

Further, we look at the impact of EEDs on research and development (R\&D) expenditures and capital expenditures. Improving environmental performance implies the adoption of environmental management practices, which impose costs on firms. In the case of GHG emissions, some of these costs may involve investments in new equipment using cleaner technologies (Clarkson et al. 2008; Fisher-Vanden and Thorburn 2011) or investments in renewable energy generation (Ortiz-de-Mandojana et al. 2012). These expenditures are likely to be classified as large capital expenditures or expenditures in research and development of new environmental technology.

We do not have consistent data on the dollar value of the investment in environmental technology. Instead, we rely on the result that the adoption of environmental management practices is linked to the level of a firm's R\&D (Anton et al. 2004) and use total capital expenditures and R\&D expenditures, of which environmental sustainability expenses will be a subset. If EEDs are appointed for their specific skills or network centrality, one channel through which they could affect environmental performance is through $\mathrm{R} \& \mathrm{D}$ and capital expenditures.

In panel $\mathrm{C}$, we present the results with natural log of $\mathrm{R} \& \mathrm{D}$ expenses as our dependent variable. Firms with EEDs and firms with better-networked EEDs have, on average, higher investments in research and development, and this positive association is statistically significant in all the four specifications. In panel D, we present the results with the natural log of capital expenditure as our dependent variable. Again, the presence of EEDs and their network centrality are positively associated with capital expenditures.

These results suggest that better-networked EEDs act as conduits of information and innovation, which is consistent with our baseline hypotheses. This might be one potential channel through which EEDs affect GHG emissions.

\section{Extensions and Robustness}

In this section, we present extensions of our main results. We also present the robustness of our findings to alternate explanations and potential misclassifications.
Table 10 EED announcement returns

\begin{tabular}{lll}
\hline & $\begin{array}{ll}\text { CAR }(-1,+1) \\
(1)\end{array}$ & $\begin{array}{l}\text { CAR }(-3,+3) \\
(2)\end{array}$ \\
\hline EED appointments & $0.013^{* *}$ & $0.008^{* *}$ \\
& $(0.005)$ & $(0.003)$ \\
Control variables & Yes & Yes \\
Year dummies & Yes & Yes \\
Industry dummies & Yes & Yes \\
Observations & 173 & 173 \\
Adjusted- $R^{2}$ & 0.187 & 0.179 \\
\hline
\end{tabular}

Robust standard errors clustered at the firm level are in brackets. $* p<0.10, * * p<0.05, * * * p<0.01$

\section{Does the Market Value EEDs?}

So far, we have examined how EEDs add value to the firm. In an interesting extension, we investigate if the market values the environmental expertise of directors. Using data on the date of announcement of director appointments from BoardEx, we conduct an event study to examine how investors react to EED appointments, controlling for firmspecific heterogeneity. We use announcement date of director appointments from FTSE 350 firms within our sample period. Appointments are excluded if the announcement date is not available, or overlaps with other major corporate announcements. This yields a sample of 173 EED appointments, and 179 other director appointments.

We calculate the market-adjusted cumulative abnormal returns (CAR) around the announcement date for 3-day and 7-day windows, and regress the CARs on the EED dummy, with firm and industry controls. In Table 10, there is a small but statistically significant announcement effect for EED appointments to boards for both 3-day and 7-day windows. ${ }^{10}$ It seems that the appointments of directors with environmental expertise are met with investor approval.

\section{Technical Expertise}

By our classification of environmental experience, we may be employing an imperfect proxy of technical expertise. In other words, EEDs could potentially be a subset of directors with technical expertise. If so, we should get a stronger effect by using a measure of technical expertise. From information on their education and career background, we construct a measure of technical directors where directors have financial, engineering, legal, and technology expertise, in

\footnotetext{
${ }^{10}$ We use information from the Announcement Date field of Boar$\mathrm{dEx}$ and check for the robustness of our results using Effective Date. The results are similar in magnitude and significance.
} 
addition to environmental expertise. Using this measure of board expertise, we re-estimate our baseline specifications. The coefficient associated with this measure of technical expertise is negative but not statistically significant at conventional levels. Therefore, it does not seem that our baseline results are capturing the effect of technical expertise. Directors with specific expertise in environmental issues seem to have an effect on GHG emissions. The results are presented in column 1 of "Appendix 6".

\section{Impact of CEO EEDs}

Fich (2005) and Fahlenbrach et al. (2010) show that firms can benefit from appointing directors who are CEOs of other firms. We identify the subsample of those firm-years where there is at least one independent non-executive director who is a CEO of another listed firm, denoted as CEO EEDs. A large proportion of EEDs, (78\%) not CEOs of other firms (non-CEO EEDs). We re-estimate our baseline specifications discussed in the first part of the Empirical Analysis section with these indicators for CEO and non-CEO environmental experience. We find that the presence of both CEO EEDs and non-CEO EEDs is associated with lower GHG emissions. The results are presented in columns 2 and 3 of "Appendix 6".

\section{Alternate Measures of Environmental Performance}

While GHG emission is the most pressing of environmental concern, other measures of environmental performance need to be considered. In alternate specifications, we test for the robustness of our results using emissions of other gases like sulfur and nitrogen oxides, ammonia, chlorofluorocarbons, etc., and hazardous and non-hazardous effluent release as measures of environmental performance. ${ }^{11}$ The results (presented in "Appendix 7") are consistent with our baseline estimates, albeit with smaller sample sizes.

\section{Conclusion}

One of the major concerns of our times is to integrate economic and environmental well-being and there is institutional pressure on firms to be environmentally responsible is increasingly enforced. Firms may adopt either symbolic or substantive measures to improve the ethical and sustainable business practices. It is likely that the board of directors will be responsible to implement and monitor such practices. Therefore, the role of the board of directors in catering to

11 We use information on both hazardous and non-hazardous effluent releases to land and water. the interests of the wider stakeholders of the firm, over and above the traditional role of shareholder value maximization, is attracting the attention of academics and regulatory authorities. In this paper, we provide some insight into the resource provision role of the board of directors in firms' adoption of substantive environmental measures, i.e., the reduction in GHG emission. Explicitly, we focus on two possible channels. First, EEDs may have skills or expertise that suit them to provide information and strategic advice on ensuring substantive ethical practices. Second, EEDs can leverage knowledge on environmental strategies through shared directorships. For example, better-networked EEDs can improve a firm's ability to respond to shocks in environmental technology or anticipate regulatory changes on sustainability and consequently improve this firm's ethical practices.

Controlling for endogeneity concerns, we find that EEDs have an economically significant impact on GHG emissions: firms with board expertise in environmental sustainability have lower GHG emissions. We test for alternative explanations, and our results suggest that the effect of EEDs is likely to be a specific expertise effect rather than due to some general or technical skills. We also find that EEDs leverage their network connections on environmental issues. Finally, the appointment of directors with environmental expertise is received positively by the market. The paper also identifies investments in green technology as a potential mechanism through which directors can influence a firm's sustainable practices. In gist, our results show that the market values the environmental expertise of directors and that these directors, through their advisory role, positively affect the adoption of substantive corporate ethical practices, e.g., investing in green technologies. In that respect, our results lend support to the debate on the role of the directors in catering to the interests of wider stakeholders of the firm.

In the light of the above findings, an obvious question arises: can corporate ethical and sustainable practices be ensured by appointment of EEDs? It is not the case for a number of reasons. First, the appointment of directors with a set of specific skills has opportunity costs. Appointing a director with environmental skills might mean keeping out a director with general or other specific skills, which might be valuable to the firm. Second, if the environmental technology is industry-specific then anti-trust laws may prohibit firms competing in the same product market to have shared directors. This constrains the supply of environmental directors to firms. Such appointments are likely to be endogenous selections where the benefits of such appointments outweigh the cost. Like voluntary compliance with environmental standards, director expertise and connectedness may not lead to better environmental performance for all firms.

Finally, corporate ethics and sustainability is a multidimensional issue, and cannot be wholly captured through 
reductionist measures of environmental pollution. The ethical and sustainability concerns of non-emitting industries can be different and our results will not be generalizable in that context. Our results, therefore, do not discount the importance of regulations on corporate ethical and sustainability practices.

Open Access This article is distributed under the terms of the Creative Commons Attribution 4.0 International License (http://creativecommons.org/licenses/by/4.0/), which permits unrestricted use, distribution, and reproduction in any medium, provided you give appropriate credit to the original author(s) and the source, provide a link to the Creative Commons license, and indicate if changes were made.

\section{Appendix 1: Variables Summary and Data Description}

\begin{tabular}{|c|c|c|}
\hline Key variables & Source & Description \\
\hline \multicolumn{3}{|c|}{ Firm characteristics } \\
\hline GHG emissions & $\begin{array}{l}\text { E-PRTR/own calcu- } \\
\text { lation }\end{array}$ & $\begin{array}{l}\text { Emission of green } \\
\text { house gases normal- } \\
\text { ized by permissible } \\
\text { threshold }\end{array}$ \\
\hline Other Gases & $\begin{array}{l}\text { E-PRTR/own calcu- } \\
\text { lation }\end{array}$ & $\begin{array}{l}\text { Emission of other gases } \\
\text { like ammonia, hydro- } \\
\text { gen sulfides, CFCs, } \\
\mathrm{NO}_{x} \mathrm{SO}_{x} \text { etc. }\end{array}$ \\
\hline Effluent release & $\begin{array}{l}\text { E-PRTR/own calcu- } \\
\text { lation }\end{array}$ & $\begin{array}{l}\text { Hazardous and non- } \\
\text { hazardous waste }\end{array}$ \\
\hline $\begin{array}{l}\text { Return on assets } \\
\text { (ROA) }\end{array}$ & $\begin{array}{l}\text { Datastream/world- } \\
\text { scope }\end{array}$ & $\begin{array}{l}\text { Net Income/Total } \\
\text { Assets }\end{array}$ \\
\hline MTBV & $\begin{array}{l}\text { Datastream/world- } \\
\text { scope }\end{array}$ & $\begin{array}{c}\text { Market value of equity/ } \\
\text { book value of equity }\end{array}$ \\
\hline Firm Age & Thompson one & Date company founded \\
\hline Sales & $\begin{array}{l}\text { Datastream/World- } \\
\text { scope }\end{array}$ & $\begin{array}{l}\text { Annual sales ('000 } \\
\text { US\$) }\end{array}$ \\
\hline Leverage & $\begin{array}{l}\text { Datastream/World- } \\
\text { scope }\end{array}$ & Debt to equity ratio \\
\hline Volatility & $\begin{array}{l}\text { Datastream/World- } \\
\text { scope }\end{array}$ & $\begin{array}{l}\text { Volatility in annual } \\
\text { stock price }\end{array}$ \\
\hline Slack & Author's calculation & $\begin{array}{l}\text { Cash or cash equiva- } \\
\text { lents/Total Assets }\end{array}$ \\
\hline HHI & Author's calculation & $\begin{array}{l}\text { Sum of squared market } \\
\text { shares of all firms in } \\
\text { an industry }\end{array}$ \\
\hline $\mathrm{R} \& \mathrm{D}$ & $\begin{array}{l}\text { Datastream/World- } \\
\text { scope }\end{array}$ & $\begin{array}{l}\text { Expenses in research } \\
\text { and development of } \\
\text { goods and } \\
\text { services as percentage } \\
\text { of total assets }\end{array}$ \\
\hline Capital expenses & $\begin{array}{l}\text { Datastream/World- } \\
\text { scope }\end{array}$ & $\begin{array}{l}\text { Capital expenditure as } \\
\text { percentage of total } \\
\text { assets }\end{array}$ \\
\hline
\end{tabular}

\begin{tabular}{|c|c|c|}
\hline Key variables & Source & Description \\
\hline \multicolumn{3}{|l|}{ Board characteristics } \\
\hline Board Size & BoardEx & $\begin{array}{l}\text { No. of directors on the } \\
\text { board }\end{array}$ \\
\hline $\begin{array}{l}\text { \% Non-executive } \\
\text { directors }\end{array}$ & BoardEx & $\begin{array}{l}\text { Fraction of independent } \\
\text { directors }\end{array}$ \\
\hline Board Tenure & Authors' calculation & $\begin{array}{l}\text { Average tenure of all } \\
\text { directors in a given } \\
\text { firm }\end{array}$ \\
\hline $\begin{array}{l}\text { \%Shareholding- } \\
\text { institutions }\end{array}$ & BoardEx & $\begin{array}{l}\text { Proportion of shares } \\
\text { held by institutions } \\
\text { like banks. }\end{array}$ \\
\hline $\begin{array}{l}\text { Environmental com- } \\
\text { mittees }\end{array}$ & BoardEx & $\begin{array}{l}\text { Binary indicator for } \\
\text { board environmental } \\
\text { committees }\end{array}$ \\
\hline CEO duality & BoardEx & $\begin{array}{l}\text { CEO is also the Chair- } \\
\text { man }\end{array}$ \\
\hline Law experts & BoardEx & $\begin{array}{l}\text { Directors with a legal } \\
\text { qualification }\end{array}$ \\
\hline CEO pay & BoardEx & $\begin{array}{l}\text { Salary+Bonus+Market } \\
\text { value of } \\
\text { shares+LTIPs+Black } \\
\text { scholes option value }\end{array}$ \\
\hline CEO turnover & Authors' calculation & $\begin{array}{l}\text { Indicator for change } \\
\text { in the CEO of a firm } \\
\text { between two years. }\end{array}$ \\
\hline EEDs & $\begin{array}{l}\text { BoardEx and public } \\
\text { sources }\end{array}$ & $\begin{array}{l}\text { Indicator that a direc- } \\
\text { tor has experience } \\
\text { in environmental } \\
\text { sustainability }\end{array}$ \\
\hline \multicolumn{3}{|l|}{ Network Centrality } \\
\hline Degree & BoardEx & $\begin{array}{l}\text { The number of a node's } \\
\text { connections (see } \\
\text { "Appendix 4") }\end{array}$ \\
\hline Closeness & BoardEx & $\begin{array}{l}\text { The ease to reach the } \\
\text { other nodes in the } \\
\text { network (see "Appen- } \\
\text { dix 4") }\end{array}$ \\
\hline Betweenness & BoardEx & $\begin{array}{l}\text { Sum of proportions for } \\
\text { all pairs of nodes } j \\
\text { and } k \text { in which node } \\
i \text { is on } \\
\text { the shortest path } \\
\text { between } j \text { and } k \text {, } \\
\text { normalized by the } \\
\text { maximum possible } \\
\text { betweenness for the } \\
\text { network (see "Appen- } \\
\text { dix 4") }\end{array}$ \\
\hline Eigen vector & BoardEx & $\begin{array}{l}\text { A node's eigenvector } \\
\text { is proportional to the } \\
\text { sum of eigenvector } \\
\text { values of all nodes } \\
\text { directly connected to } \\
\text { it (see "Appendix 4") }\end{array}$ \\
\hline
\end{tabular}




\section{Appendix 2: GHG Emissions Algorithm}

As a measure of firms' environmental performance, we use firms' GHG emission data from the E-PRTR (Website: http://prtr.ec.europa.eu/). The E-PRTR is the Europe-wide register that provides annual data on the amounts of pollutant releases to air, water, and land from 93 key pollutants (e.g., heavy metals, pesticides, greenhouse gases, and dioxins) as well as off-site transfers of waste and of pollutants in waste water from 43,464 industrial facilities in the EU Member States, Iceland, Liechtenstein, Norway, Serbia, and Switzerland over the period 2007-2014. The main advantage of the register is that data are comparable across countries and pollutants because data collection and reporting are standardized over all pollutants in all countries. A facility is defined as an operation unit of a firm focused on a narrowly defined process like packaging, bottling, etc.

Our original dataset downloaded from the E-PRTR website contains 561,075 observations. Each line of the dataset reports data on one particular pollutant released/transferred by one facility in one year as well as information about the category of the pollutant (greenhouse gas, pesticide, etc.) and information about the facility (e.g., address, activity sector, parent company, etc.). As a consequence, we may have several observations for the same facility within a year if this facility releases or transfers various types of pollutants per year. For example, the facility with ID $=9$ (Saint-Gobain Glass Polska Sp. Z o. o.) has three lines for the year 2011 in the dataset because this facility released two types of pollutant (NOx and Cadmium) and reported hazardous waste disposal in 2011.

As we are not interested in one particular pollutant, we aggregate pollutants in 7 categories defined on the E-PRTR website: Chlorinated organic substances, greenhouse gases (our variable of interest), heavy metals, inorganic substances, other gases, other organic substances, pesticides. We have also two categories for waste: hazardous and nonhazardous. Since the harmfulness of each pollutant differs and also the relative amount of each pollutant emitted differs, we cannot simply add the individual amounts of each pollutant to aggregate them in these 7 categories.

Each pollutant is reported in the E-PRTR if the emitted amount exceeds a reporting threshold. The reporting thresholds are set up by the European Commission based on their impact on human health and on the environment. ${ }^{12}$ We therefore normalize the emitted amount according to the reporting threshold and then sum these normalized amounts

\footnotetext{
12 See Article 5 of the E-PRTR Regulation No 166/2006 of the European Parliament and of the Council of 18 January 2006 concerning the establishment of a European Pollutant Release and Transfer Register and amending Council Directives 91/689/EEC and 96/61/EC.
}

of pollutant belonging to the same category for each individual facility.

We finally reshape the dataset to have only one observation per facility per year. Our dataset has now 208,735 lines. Each line contains information on the facility (address, parent company, and economic activity code) and the amount of pollutant by category. From this dataset, we extract all the facilities belonging to UK firms featured in the FTSE350 and aggregate pollution data at the firm level as explained in the Data Section of our paper.

\section{Appendix 3: Board Expertise Algorithm}

To identify directors with environmental expertise, we use data from BoardEx on the education and past expertise of directors in matters related to environmental sustainability. We classify directors as having prior experience in environmental issues if they have served on any of the following board-level committees in a previous role:

1. Health, Safety, Security, and Environment

2. Safety and Sustainable Development

3. Sustainability and Stakeholder Management

4. Corporate Responsibility

5. Sustainability

6. Safety, Ethics, and Environmental Assurance

7. Corporate Social Responsibility

8. Sustainable and Responsible Business

9. Health, Safety, Environment and Community

10. Ethics-Compliance-Corporate Responsibility

11. Safety, Health, and Environment

12. Sustainable Development

13. Risk and CSR

14. Environment, Health and Safety

15. CSR and Regulatory Issues

16. Corporate Compliance and Responsibility

In order to test for the robustness of our results, we also construct different measures by random sampling of these keywords. Data on EEDs are available from the authors' websites on request.

\section{Appendix 4: EEDs Centrality Measures}

The concept of centrality is multidimensional. In this paper, we focus on the four commonly used measures of centrality (see Jackson 2010; Larcker et al. 2013): Degree, Eigenvector, Closeness and Betweenness. We compute these measures for each EED in the network formed by shared directorship. To aggregate these measures at the board level, we compute the average centrality measures of the EEDs on the 
board. We discuss the relevance of each of these measures below:

\section{Degree}

The simplest centrality measure is the count of the number of connections. A higher degree reflects more pathways to access to information, and expertise. The degree centrality varies over time due to entry and exit of directors, and is normalized by $n-1$, where $n$ is the number of directors in the network.

Degree $_{i}=\sum_{j \neq i} d_{i j}$

$d_{i j}$ is equal to 1 if directors $i$ and $j$ sit on the same board and 0 otherwise.

\section{Eigenvector}

It can be argued that a director is more influential when his individual connections are also well-networked. Unlike degree, which weights every link equally, the eigenvector weights links according to their eigenvector values. A nodes' eigenvector is proportional to the sum of the eigenvector values of all nodes directly connected to it. It is useful in determining who is connected to the most connected nodes. The eigenvector of a node is defined as

$e_{i}=\lambda^{-1} \sum_{j \neq i} d_{i j} e_{j}$

where $\lambda$ is the eigenvalue. In our context, it is important to measure how central a director is in terms of its own degree but it also important to take into account the degrees of the directors he is connected to. If director $i$ is connected to director $j$, who is very well connected (i.e., has a high degree), then director $i$ has a greater opportunity to get access to information or influence the rest of network.

\section{Closeness}

This measures the ease to reach other nodes or how long it will take to spread information from one director to all other directors sequentially.

Closeness $_{i}=\frac{n-1}{\sum_{j \neq i} l_{i j}}$

where $l_{i j}$ is the distance between directors $i$ and $j$. In our network, a high closeness indicates a director who is close to others and can therefore quickly interact and communicate with them without going through many intermediaries. High closeness makes information transmission quicker.

\section{Betweenness}

The betweenness of a node is a measure of its role as an intermediary. Formally, node $i$ betweenness is the sum of proportions for all pairs of nodes $j$ and $k$ in which node $i$ is on the shortest path between $j$ and $k$. It is normalized by the maximum possible betweenness for the network with $n$ nodes. Mathematically, It is defined as

Betweenness $_{i}=\sum_{j, k \neq i} \frac{P_{i}(j, k) / P(j, k)}{(n-1)(n-2) / 2}$

where $P(j, k)$ is the number of shortest paths between $j$ and $k$ and $P_{i}(j, k)$ is the number of shortest paths between $j$ and $k$ that goes through $i$. Directors with high betweenness are on the path of a large number of information flows and as such, able to influence a large number of directors as well as be able to collect information quickly from many sources.

\section{Appendix 5: Univariate Comparison of Firms with and without EEDs}

\begin{tabular}{|c|c|c|c|}
\hline & \multicolumn{2}{|l|}{ Means } & \multirow[t]{2}{*}{ Difference } \\
\hline & Firms with EEDs & $\begin{array}{l}\text { Firms } \\
\text { without } \\
\text { EEDs }\end{array}$ & \\
\hline ROA & 7.214 & 7.988 & -0.784 \\
\hline MTBV & 1.512 & 1.498 & 0.014 \\
\hline Ln sales & 17.248 & 17.507 & -0.259 \\
\hline Leverage & 0.575 & 0.560 & 0.015 \\
\hline Volatility & 0.034 & 0.040 & -0.006 \\
\hline Slack & 0.226 & 0.221 & 0.005 \\
\hline $\begin{array}{l}\text { GHG emissions (nor- } \\
\text { malized) }\end{array}$ & 10.409 & 14.751 & $-4.432 * * *$ \\
\hline $\mathrm{R} \& \mathrm{D}$ & 0.049 & 0.047 & 0.002 \\
\hline Capital expenditure & 0.603 & 0.586 & 0.017 \\
\hline Firm Age & 2.898 & 3.137 & 0.239 \\
\hline HHI & 0.203 & 0.214 & -0.011 \\
\hline $\begin{array}{l}\text { \%Shareholding-insti- } \\
\text { tutions }\end{array}$ & 30.018 & 28.503 & 1.515 \\
\hline Board Size & 8.648 & 7.501 & $1.147 * *$ \\
\hline $\begin{array}{l}\% \text { Non-executive direc- } \\
\text { tors }\end{array}$ & 55.013 & 55.304 & -0.291 \\
\hline CEO Duality & 0.228 & 0.235 & -0.007 \\
\hline Law Expert & 1.07 & 1.24 & -0.17 \\
\hline Average Board Tenure & 6.18 & 6.39 & -0.19 \\
\hline
\end{tabular}




\begin{tabular}{|c|c|c|c|}
\hline & \multicolumn{2}{|l|}{ Means } & \multirow[t]{2}{*}{ Difference } \\
\hline & Firms with EEDs & $\begin{array}{l}\text { Firms } \\
\text { without } \\
\text { EEDs }\end{array}$ & \\
\hline Degree & 7.225 & 8.543 & $-1.318^{* *}$ \\
\hline Closeness & 0.288 & 0.285 & 0.003 \\
\hline Betweenness & 0.015 & 0.011 & 0.004 \\
\hline Eigen Vector & 0.049 & 0.039 & 0.010 \\
\hline
\end{tabular}

Robust standard errors clustered at the firm level are in brackets

$* p<0.10, * * p<0.05, * * * p<0.01$ (2-tailed)

\section{Appendix 6: Robustness of EED Classifications}

\begin{tabular}{llll}
\hline \multirow{2}{*}{ Technical directors } & \multicolumn{3}{l}{ Dependent variable: GHG emissions } \\
\cline { 2 - 4 } & $(1)$ & $(2)$ & $(3)$ \\
\hline CEO EEDs & $(0.010)$ & & \\
& & $-0.011^{* *}$ & \\
Non-CEO EEDs & & $(0.005)$ & \\
& & & $-0.021^{* *}$ \\
Firm covariates & Yes & Yes & $(0.009)$ \\
Year dummies & Yes & Yes & Yes \\
Firm fixed effects & Yes & Yes & Yes \\
Constant & $0.179^{* * *}$ & $0.189^{* * *}$ & $0.206^{* * *}$ \\
& $(0.033)$ & $(0.055)$ & $(0.065)$ \\
Observations & 3244 & 3244 & 3244 \\
Adjusted $R^{2}$ & 0.107 & 0.189 & 0.264 \\
\hline
\end{tabular}

Robust standard errors clustered at the firm level are in brackets $* p<0.10, * * p<0.05, * * * p<0.01$

\section{Appendix 7: EEDs and Other Measures of Pollution}

\begin{tabular}{ll} 
Dependent variables & \\
\hline Other gases & Effluent release \\
$(1)$ & $(2)$ \\
\hline$-0.011^{* *}$ & $-0.008^{*}$ \\
$(0.003)$ & $(0.005)$ \\
Yes & Yes \\
Yes & Yes
\end{tabular}

Dependent variables

Other gases $\quad$ Effluent release

(1)

\begin{tabular}{lll}
\hline Firm fixed effects & Yes & No \\
Constant & $0.018^{* *}$ & $0.027^{* *}$ \\
& $(0.010)$ & $(0.013)$ \\
Observations & 2086 & 1997 \\
Adjusted $R^{2}$ & 0.180 & 0.163 \\
\hline
\end{tabular}

Robust standard errors clustered at the firm level are in brackets

$* p<0.10, * * p<0.05, * * * p<0.01$

\section{References}

Acemoglu, D., Akcigit, U., \& Celik, M. A. (2014). Young, restless and creative: Openness to disruption and creative innovations, National Bureau of Economic Research Working Paper No. 198994

Adams, R. B., Hermalin, B. E., \& Weisbach, M. S. (2010). The role of board of directors in corporate governance: A conceptual framework and survey. Journal of Economic Literature, 48(1), 58-107.

Adams, R. (2003). What do boards do? Evidence from board committee and director compensation data. Unpublished working paper. Federal Reserve Bank of New York, New York.

Angrist, J. D., \& Pischke, J. S. (2008). Mostly harmless econometrics: An empiricist's companion. Princeton, NJ: Princeton University Press.

Anton, W. R. Q., Deltas, G., \& Khanna, M. (2004). Incentives for environmental self regulation and implications for environmental performance. Journal of Environmental Economics and Management, 48(1), 632-654.

Bebchuk, L. A., \& Weisbach, M. S. (2010). The state of corporate governance research. Review of Financial Studies, 23(3), 939-961.

Berrone, P., \& Gomez-Mejia, L. (2009). Environmental performance and executive compensation: An integrated agency-institutional perspective. Academy of Management Journal, 52(1), 103-126.

Billmoria, D., \& Piderit, S. K. (1994). Board committee membership: Effects of sex-selected bias. The Academy of Management Journal, 37(6), 1453-1477.

Boyd, B. K. (1994). Board control and CEO compensation. Strategic Management Journal, 15(5), 335-344.

Byrd, J. W., \& Hickman, K. A. (1992). Do outside directors monitor managers? Journal of Financial Economics, 32(2), 195-221.

Chhaochharia, V., \& Grinstein, Y. (2009). CEO compensation and board structure. Journal of Finance, 64(1), 231-261.

Clarkson, P., Li, Y., Richardson, G., \& Vasvari, F. (2008). Revisiting the relation between environmental performance and environmental disclosure: An empirical analysis. Accounting, Organizations and Society, 33(4-5), 303-327.

Cohen, J. G., Krishnamoorthy, G., \& Wright, A. M. (2004). The corporate governance mosaic and financial reporting quality. Journal of Accounting Literature, 23, 87-152.

Coles, J. L., Daniel, N. D., \& Naveen, L. (2008). Boards: Does one size fit all? Journal of Financial Economics, 87(2), 329-356.

Dass, N., Kini, O., Nanda, V., Onal, B., \& Wang, J. (2014). Board expertise: Do directors from related industries help bridge the information gap? Review of Financial Studies, 27(5), 1533-1592. 
de Villiers, C., Naiker, V., \& van Staden, C. J. (2011). The effect of board characteristics on environmental performance. Journal of Management, 37(6), 1636-1663.

Di Giuli, A., \& Kostovetsky, L. (2014). Are red or blue companies more likely to go green? Journal of Financial Economics, 111(1), $158-80$.

Elsayed, K. (2006). Reexamining the expected effect of available resources and firm size on firm environmental orientation: An empirical study of UK firms. Journal of Business Ethics, 65(3), 297-308.

Fahlenbrach, R., Low, A., \& Stulz, R. (2010). Why do firms appoint CEOs as outside directors? Journal of Financial Economics, 97(1), 12-32.

Fama, E., \& Jensen, M. C. (1983). Separation of ownership and control. Journal of Law and Economics, 26(2), 301-325.

Fich, E. M. (2005). Are some outside directors better than others? Evidence from director appointments by fortune 1000 firms. Journal of Business, 78(5), 1943-1972.

Fich, E. M., \& Shivdasani, A. (2006). Are busy boards effective monitors? Journal of Finance, 61(2), 689-724.

Fisher-Vanden, K., \& Thorburn, K. S. (2011). Voluntary corporate environmental initiatives and shareholder wealth. Journal of Environmental Economics and Management, 62(3), 430-445.

Garmaise, M., \& Moskowitz, T. (2003). Informal financial networks: Theory and evidence. Review of Financial Studies, 16(7), $1007-1040$.

Gomes-Casseres, B., Hagedoorn, J., \& Jaffe, A. (2006). Do alliances promote knowledge flows? Journal of Financial Economics, $80(1), 5-33$.

Goldman, E., Rocholl, J., \& So, J. (2009). Do politically connected boards affect firm value? Review of Financial Studies, 22(6), 2231-2260.

Güner, B. A., Malmendier, U., \& Tate, G. (2008). Financial expertise of directors. Journal of Financial Economics, 88(2), 323-354.

Guo, L., \& Masulis, R. W. (2015). Board structure and monitoring: New evidence from CEO turnovers. Review of Financial Studies, 28(10), 2770-2811.

Hochberg, Y., Ljungqvist, A., \& Lu, Y. (2007). Whom you know matters: Venture capital networks and investment performance. The Journal of Finance, 62(1), 251-301.

Hwang, B.-H., \& Kim, S. (2009). It pays to have friends. Journal of Financial Economics, 93(1), 138-158.

Jackson, M. O. (2010). Social and economic network. Princeton: Princeton University Press.

Johnson, R. A., \& Greening, D. W. (1999). The effects of corporate governance and institutional ownership types on corporate social performance. Academy of Management Journal, 42(5), 564-576.

Kassinis, G., \& Vafeas, N. (2002). Corporate boards and outside stakeholders as determinants of environmental litigation. Strategic Management Journal, 23(5), 399-415.

Klassens, R. D., \& McLaughlin, C. P. (1996). The impact of environmental management on firm performance. Management Science, 42(8), 1199-1214

Khlif, H., Hussainey, K., \& Achek, I. (2015). The effect of national culture on the association between profitability and corporate social and environmental disclosure: A meta-analysis. Meditari Accountancy Research, 23(3), 296-321.

Knyazeva, A., Knyazeva, D., \& Masulis, R. (2013). The supply of corporate directors and board independence. Review of Financial Studies, 26(6), 1561-1605.

Konar, S., \& Cohen, M. A. (2001). Does the market value environmental performance? Review of Economics and Statistics, 83(2), 281-289.

Larcker, D. F., So, E. C., \& Wang, C. C. Y. (2013). Boardroom centrality and firm performance. Journal of Accounting and Economics, $55(2-3), 225-250$.

Laufer, W. S. (2003). Social accountability and corporate greenwashing. Journal of Business Ethics, 43(3), 253-261.

Laux, C., \& Laux, V. (2009). Board committees, CEO compensation, and earnings management. The Accounting Review, 84(3), 869-891.

Linck, J., Netter, J., \& Yang, T. (2008). The effects and unintended consequences of the Sarbanes Oxley Act on the supply and demand for directors. Review of Financial Studies, 22(8), 3287-3328.

Masulis, R. W., \& Mobbs, S. (2011). Are all inside directors the same? CEO entrenchment and board entrenchment. Journal of Finance, 66(3), 823-872.

McKendall, M., Sánchez, C. M., \& Sicilian, P. (1999). Corporate governance and corporate illegality: The effects of board structure on environmental violations. International Journal of Organizational Analysis, 7(3), 201-223.

Ortiz-de-Mandojana, N., Aragón-Correa, J. A., Delgado-Ceballos, J., \& Ferrón-Vílchez, V. (2012). The effect of director interlocks on firms' adoption of proactive environmental strategies. Corporate Governance: An International Review, 20(2), 164-178.

Pfeffer, J., \& Salancik, G. R. (1978). The external control of organizations: A resource dependence perspective. New York: Harper \& Row.

Rao, K., \& Tilt, C. (2016). Board composition and corporate social responsibility: The role of diversity, gender, strategy and decision making. Journal of Business Ethics, 138(2), 327-347.

Stevens, J. M., Steensma, K. H., Harrison, D. A., \& Cochran, P. L. (2005). Symbolic or substantive document? The influence of ethics codes on financial executives' decisions. Strategic Management Journal, 26(2), 181-195.

Walker, K., \& Wan, F. (2012). The harm of symbolic actions and green-washing: Corporate actions and communications on environmental performance and their financial implications. Journal of Business Ethics, 109(2), 227-242.

Walls, J. L., Berrone, P., \& Phan, P. H. (2012). Corporate governance and environmental performance: Is there really a link? Strategic Management Journal, 33(8), 885-913.

Weisbach, M. S. (1988). Outside directors and CEO turnover. Journal of financial Economics, 20(1), 431-460.

Westphal, J. D., \& Zajac, E. J. (1998). The symbolic management of stockholders: Corporate governance reforms and shareholder reactions. Administrative Science Quarterly, 43(1), 127-153. 